\title{
Ferroptosis: Cancer Stem Cells Rely on Iron until "to Die for" It
}

\author{
Emma Cosialls ${ }^{1}$, Rima El Hage ${ }^{1}$, Leïla Dos Santos ${ }^{1}$, Chang Gong ${ }^{2}$, Maryam Mehrpour ${ }^{1, *}$ and Ahmed Hamaï ${ }^{1, *} \mathbb{C}$ \\ 1 Institut Necker-Enfants Malades (INEM), Inserm U1151-CNRS UMR 8253, \\ Université Paris Descartes-Sorbonne Paris Cité, F-75993 Paris, France; emma.cosialls@inserm.fr (E.C.); \\ rima.elhage@inserm.fr (R.E.H.); leila.dos-santos@inserm.fr (L.D.S.) \\ 2 Breast Tumor Center, Sun Yat-sen Memorial Hospital, Guangzhou 510120, China; gchang@mail.sysu.edu.cn \\ * Correspondence: maryam.mehrpour@inserm.fr (M.M.); ahmed.hamai@inserm.fr (A.H.)
}

Citation: Cosialls, E.; El Hage, R.; Dos Santos, L.; Gong, C.; Mehrpour, M.; Hamaï, A. Ferroptosis: Cancer Stem Cells Rely on Iron until “to Die for" It. Cells 2021, 10, 2981. https:// doi.org/10.3390/cells10112981

Academic Editor: George Simos

Received: 29 September 2021

Accepted: 29 October 2021

Published: 2 November 2021

Publisher's Note: MDPI stays neutral with regard to jurisdictional claims in published maps and institutional affiliations.

Copyright: (c) 2021 by the authors. Licensee MDPI, Basel, Switzerland. This article is an open access article distributed under the terms and conditions of the Creative Commons Attribution (CC BY) license (https:// creativecommons.org/licenses/by/ $4.0 /)$.

\begin{abstract}
Cancer stem cells (CSCs) are a distinct subpopulation of tumor cells with stem cell-like features. Able to initiate and sustain tumor growth and mostly resistant to anti-cancer therapies, they are thought responsible for tumor recurrence and metastasis. Recent accumulated evidence supports that iron metabolism with the recent discovery of ferroptosis constitutes a promising new lead in the field of anti-CSC therapeutic strategies. Indeed, iron uptake, efflux, storage and regulation pathways are all over-engaged in the tumor microenvironment suggesting that the reprogramming of iron metabolism is a crucial occurrence in tumor cell survival. In particular, recent studies have highlighted the importance of iron metabolism in the maintenance of CSCs. Furthermore, the high concentration of iron found in CSCs, as compared to non-CSCs, underlines their iron addiction. In line with this, if iron is an essential macronutrient that is nevertheless highly reactive, it represents their Achilles' heel by inducing ferroptosis cell death and therefore providing opportunities to target CSCs. In this review, we first summarize our current understanding of iron metabolism and its regulation in CSCs. Then, we provide an overview of the current knowledge of ferroptosis and discuss the role of autophagy in the (regulation of) ferroptotic pathways. Finally, we discuss the potential therapeutic strategies that could be used for inducing ferroptosis in CSCs to treat cancer.
\end{abstract}

Keywords: iron metabolism; ferroptosis; autophagy; cancer stem cells

\section{Introduction}

Iron is an essential nutrient in all mammals and is involved in key biological processes (as a catalytic component of various proteins), including hemoglobin synthesis (heme), DNA synthesis (ribonucleotide reductase), oxygen transport (hemoglobin), mitochondrial respiration (electron transport chain), energy metabolism (aconitase, succinate dehydrogenase), detoxification (cytochrome P450 enzymes), antioxidant defense (catalase), oxygen sensing (hypoxia-inducible factor (HIF) and prolylhydroxylases) and immune defense (myeloperoxidase). This property is based on the chemical transitional ability of iron to fluctuate between an oxidized form $\left(\mathrm{Fe}^{3+}\right.$, ferric state, electron acceptor) and a reduced form $\left(\mathrm{Fe}^{2+}\right.$, ferrous state, electron donator) in various enzymatic or redox reactions. However, although iron is tightly regulated, excess free iron in cells can also contribute to the formation of free radicals from reactions with oxygen and excess free radicals, leading to lipid peroxidation, the increased production of reactive oxygen species (ROS), oxidative stress, and DNA damage. Thus, iron represents a double-edged sword. Indeed, the accumulation of iron and ROS is linked to various pathologies, including iron overload diseases and cancer. Furthermore, cancer cells exhibit increased iron demand compared to non-cancer cells. In line with this, the pathways of iron uptake, storage, mobilization, trafficking, and regulation are all perturbed in cancer, suggesting that the reprogramming of iron metabolism is a central aspect of tumor cell survival. Anemia is frequently observed in many patients with cancer, and iron homeostasis dysregulation is implicated in numerous types of cancers [1-3]. The results of several experimental and epidemiological studies 
support the effect of dietary and systemic iron on tumor development. Readers interested in more details about iron homeostasis and disorders in cancer cells and tissues should read the several recent reviews on this topic [4-7]. Importantly, recent studies have shed light on the role of iron metabolism in cancer stem cells (CSCs) and suggested that the specific targeting of iron metabolism in CSCs may improve the efficacy of cancer therapy. This iron dependency can make CSC and non-CSC cells more vulnerable to a newly identified form of programmed cell death, referred to as ferroptosis. This cell death process characterized by the iron-dependent accumulation of lipid peroxides is morphologically, biochemically, and genetically distinct from other well-known forms of regulated cell death, including apoptosis, various forms of necrosis, and autophagy. In some cases, metabolic reprogramming has been linked to an acquired sensitivity to ferroptosis, thus opening new opportunities to treat tumors that are unresponsive to other conventional therapies.

\section{Iron and CSC}

Characterized by several markers (CD44, CD24, ALDH1, and CD133 which are summarized in Table 1; for a review, please see [8]), CSCs are subpopulations of cancer cells within liquid and solid tumors that share similar features to those of normal progenitor/stem cells, such as self-renewal and multi-lineage differentiation abilities, which drive the tumor growth and heterogeneity. Demonstrated to be resistant to conventional therapies both in vitro and in vivo, CSCs are thought to be responsible for tumor recurrence and metastasis [9]. Under the CSC paradigm, all tumor cells are not uniform, but tumors fit in a hierarchical organization driven by CSCs [9]. A new relationship between CSCs and iron has recently been highlighted by several laboratories including our team (now called FEROSTEM: "FER" for iron and "STEM" for stem cells).

Table 1. CSC-related markers in different cancers. Some of them (indicated in bold) are connected with iron homeostasis.

\begin{tabular}{|c|c|c|}
\hline Markers & Cancer & Ref \\
\hline CD44+CD24- & Breast & {$[10,11]$} \\
\hline ALDH1+ & $\begin{array}{c}\text { Colon, Brain, Acute Myeloid } \\
\text { Leukemia, Breast, Stomach, } \\
\text { Melanoma }\end{array}$ & [12-17] \\
\hline CD133+ & $\begin{array}{l}\text { Brain, Colon, Pancreas, Lung, } \\
\text { Ovarian, Prostate, Stomach }\end{array}$ & {$[18,19]$} \\
\hline CD44+ALDH1+ & Ovary & {$[10,20]$} \\
\hline CD44+a2b1 ${ }^{\text {high }}$ CD133+ & Prostate & {$[10,18,21]$} \\
\hline ABCB5 & Melanoma & [22] \\
\hline CD44+ & Colon, Head and Neck & {$[10,23,24]$} \\
\hline CD24+ & Colon & [25] \\
\hline CD166+ & $\begin{array}{l}\text { Colon, non-small cell lung } \\
\text { cancer }\end{array}$ & [26-28] \\
\hline CD133+EpCAM+ & Liver & {$[18,29]$} \\
\hline CD44+EpCAM+ & Colon & {$[10,23]$} \\
\hline ESA+CD44+CD24+ & Pancreas & {$[30]$} \\
\hline $\mathrm{CBX} 3+\mathrm{ABCA} 5+$ & Osteosarcoma & [31] \\
\hline LGR5+ & Colon & [32] \\
\hline CD90+ & Liver & [33] \\
\hline CD34+CD38- & Acute Myeloid Leukemia & [34] \\
\hline CD34+CD38+CD19+/CD34+CD38-CD19+ & Leukemia & [35] \\
\hline
\end{tabular}

ABC, ATP-binding cassette; ALDH1, Aldehyde dehydrogenase 1; CBX3, Chromobox homolog 3; EpCAM, Epithelial cell adhesion molecule; ESA, Epithelial specific antigen; LGR5, Leucine Rich repeated-containing G-protein coupled receptor 5 . 


\subsection{Iron Homeostasis at Cellular Level}

Briefly, the transferrin (Tf) pathway is mainly used by both normal and cancer epithelial cells for iron uptake. The complex formed between Tf associated with 2 ferric ions $\left(\mathrm{Fe}^{3+}\right)$ binds to its receptor transferrin receptor 1 (TFR1/TRFC), at the cell surface and is endocytosed. In endosomes, these ions are released at low $\mathrm{pH}(5.2-5.5)$ and reduced to $\mathrm{Fe}^{2+}$ by the ferrireductase six epithelial transmembrane antigens of the prostate 3 (STEAP3). Once in their ferrous form $\left(\mathrm{Fe}^{2+}\right)$, they are transported to the cytosol by divalent metal ion transporter 1 (DMT1/Nramp2). The Tf/TFR1 complex is then recycled to the cell surface. Other iron/metal transporters at the membrane surface have been described, including ZIP8/14, which functions optimally at $\mathrm{pH} 7.5$ in the non-transferrin-bound iron pathway. Once in the cytosol, $\mathrm{Fe}^{2+}$ ions constitute a labile intermediate pool or labile iron pool (LIP). Cellular free iron participates in several biological processes in different cellular compartments, as described above. As excess amounts of free iron can be toxic for the cells, it is stored in ferritin or exported by ferroportin (FPN) with the assistance of the ceruloplasmin ferroxidase [4]. Ferritin is a macromolecular complex with 24 subunits formed by light and heavy chains of ferritin (FTL and FTH, respectively) with the ability to store up to 4500 iron atoms. Iron exportation is regulated at the systemic level by hepcidin (a peptide hormone secreted by the liver and a master regulator of systemic iron metabolism) by binding FPN and promoting its phosphorylation and subsequent lysosomal degradation [36,37].

\subsection{Iron Metabolism Dysregulation as a Hallmark of CSCs}

In the case of CSCs in glioblastoma, Schonberg et al. reported an increase in the expression level of transferrin and TFR1 compared to non-CSCs [38]. They demonstrated that these CSCs uptake iron from the microenvironment more efficiently than their non-CSC counterparts through iron-tracing experiments. At the functional level, the authors showed that TFR1 and ferritin are crucial for the maintenance of CSCs in vivo underlining the crucial role of iron in these subpopulations. In breast cancer, we showed that cellular iron and Tf uptake, which is correlated with a higher level of TFR1 expression, is more robust in CSCs than in non-CSC counterparts [39,40]. Overall, this finding supports the existence of enhanced iron trafficking in CSCs, underlining the importance of iron in the behavior of these subpopulations. Moreover, the first demonstration of the novel role of iron via hydroxyl radicals in CSC regulation was performed in non-small lung cancer cells, showing its importance in aggressive cancer behaviors and likely metastasis through SOX9 upregulation [41]. In other in vitro CSC model based on tumorspheres derived from MCF-7 cells, iron uptake, LIP, iron mitochondria, and cell death induced by iron chelators are also enhanced in spheres compared to monolayer cell cultures [42]. Furthermore, the authors identified a transcriptional signature based on 10 genes related to iron metabolism to distinguish MCF-7 cells resistant to tamoxifen that display CSC features, as well as to distinguish CSC leukemia from non-CSC leukemia in a mice model of acute promyelocytic leukemia. Accordingly, FPN is also down-regulated in cholangiocarcinoma CSCs, promoting iron retention. In addition, low FTH levels and high TFR1 expression (as a typical pattern indicative of low iron needs) are displayed in cholangiocarcinoma cells grown in monolayers, whereas the opposite situation occurred when the same cholangiocarcinoma cell lines were allowed to form tumorspheres, accompanied with an increase in iron content and oxidative stress [43]. In line with this, through GDF (growth differentiation factor)15/SMADs-mediated regulation, hepcidin has been shown to be upregulated in MCF-7 spheroid cell cultures compared to 2D-monolayer conditions [44]. GDF15/MIC-1, which is a member of the TGF-b superfamily [45], has been even described to play a role in the enhanced invasion as well as maintenance of breast CSCs [46,47]. In ovarian cancer, an increase has also been seen in the expression level of TFR1, in contrast to a decrease in the expression level of FPN in CSCs compared to their non-CSC counterparts. This promotes higher levels of intracellular iron and hence a higher dependency on iron in CSCs. This is supported by the fact that intracellular iron reduction interferes with their proliferation in vitro and their tumorigenicity in vivo. In addition, iron increases metastatic 
spread by facilitating invasion through the expression of matrix metalloproteases and IL-6 synthesis [48]. Accordingly, iron supplementation has been found to promote CSC-like features in breast [39,40], lung [41], and cholangiocarcinoma cancer cells [43], whereas exposure to iron chelator was shown to have an opposite effect on spheroid formation ability in lung [41] and cholangiocarcinoma cancer cells [43]. Overall, this supports the notion that CSCs in various histological tumors are heavily dependent on iron; however, the role of iron in the biology/plasticity of CSCs remains to be clarified.

\subsection{Iron-Related Stemness Features/Markers}

As illustrated in Table 1, some CSC-related markers or signaling pathways have been described to be connected with iron metabolism. Figure 1 summarizes the role of iron metabolism in supporting CSC maintenance in a comparison of cancer cells. For example, CD44, which is frequently used as a CSC marker, has been demonstrated as an actor in iron acquisition in CSC by the glycosaminoglycan-mediated endocytosis of iron through its interaction with hyaluronates [10]. In addition, CD44 itself is transcriptionally regulated by nuclear iron illustrating a positive feedback loop in contrast to the IRP-mediated negative regulation of TFR1/DMT1 by excess iron. CD133 is also itself regulated by iron and its expression at the plasma membrane has an impact on the endocytosis of Tf/TFR1 or iron uptake supporting the existence of a transferrin-CD133-iron network [18]. Moreover, iron is able to increase the expression of CSC markers through the WNT signaling pathway. Indeed, a high-throughput WNT inhibitor screen revealed the critical iron dependance of beta-catenin/WNT signaling in cancers and iron chelation represents as an effective way to inhibit WNT signaling [49]. In line with this, iron exposure is also thought to affect the expression of Hedgehog Interacting Protein Like-2 (HHIPL2), an inhibitor of the hedgehog signaling pathway [50], and, contrastingly, to increase the expression of GLI1, promoting the self-renewal and maintenance of CSCs by activating the transcription of stemness genes such as CD44 and pluripotent transcription factors including NANOG, SOX2 and OCT4 [51].

\subsection{Iron Regulation and Stemness Behaviors}

Through the JAK/STAT3 pathway, which has been demonstrated to be an important pathway for CSC plasticity, both interleukin(IL)-6 and oncostatin M (OSM) (belonging to the same family of pro-inflammatory cytokines) are robust inductors of CSCs or promote the selection and expansion of CSC subpopulations [52-55]. Notably, we demonstrated that concomitant with the emergence of breast CSCs, OSM increases the expression of ferritin and the down-regulation of ferritin expression by RNA interference affects the OSM-induced enrichment of CSCs, confirming the crucial role of iron metabolism in the maintenance/plasticity of CSCs [39]. In addition, the silencing of FTH expression is also able to modulate the expression of some CSC markers and spheroid formation in other solid tumor types $[38,56]$. Several studies have supported the notion that redox status has an important impact on stem cell maintenance $[57,58]$. Indeed, high levels of ROS lead to both the loss of self-renewal and differentiation and the enhancement of the radio-susceptibility of CSCs in several types of cancer, such as breast, glioblastoma and prostate [59-61]. Interestingly, FTH with its ferroxidase activity represents a major antioxidant protein limiting iron-mediated oxidative stress. Accordingly, it has been shown that the FTH1 gene silencing in human embryonic stem cells (ESCs) leads to the overactivation of the nuclear factor (erythroid-derived-2)-like 2 (NRF2) signaling pathway and pentose phosphate metabolic pathway (PPP) to maintain the redox status [62]. Nevertheless, the silencing of FTH1 in human erythroleukemia blast cells affects their erythroid fate underlining the role of FTH in cancer cell differentiation [63]. In addition, the downregulation of FTH expression overcomes chemoresistance in solid tumors through the modulation of ROS [64]. With regard to CSC expansion, it is well established that the epithelial-to-mesenchymal transition (EMT) process in cancer cells is accompanied by the acquisition of CSC properties [65]. In line with this, FTH expression is able to modulate both the EMT in a variety of solid cancer 
in vitro models [66-68] and the EMT-like trans-differentiation process in hematological cancer models [69], mainly (but not exclusively) through its ability to regulate the amount of iron-dependent ROS. Accordingly, the depletion of ferritin in glioblastoma stem-like cells affected their proliferation/cell cycle progression through the STAT3-Forkhead box protein M1(FOXM1) regulatory axis, revealing an iron-regulated CSC pathway [38]. STAT3 activation and the transcription factor FOXM1, which is both downstream target gene and inductor of STAT3, thus constituting an activation feedback loop, are required to promote glioblastoma CSC self-renewal and tumorigenicity [38,70]. In particular, the authors postulated that the increased level of ferritin in CSCs directly interacts with STAT3 and/or potentiates STAT3 phosphorylation and leads to the activation of downstream signaling targets including FOXM1, thus illustrating iron metabolism via a ferritin-STAT3 - FOXM1 feedback loop. In line with this, AlkB homologue 5 (ALKBH5), a demethylase of the mRNA modification N6-methyladenosine $\left(\mathrm{m}^{6} \mathrm{~A}\right)$, regulates the expression of the FOXM1 gene by acting in concert with a long noncoding RNA antisense to FOXM1 (FOXM1-AS) on pre-mRNA stability in glioblastoma CSCs [71]. ALKBH5 belongs to the AlkB family of nonheme $\mathrm{Fe}$ (II)/alpha-ketoglutarate-dependent dioxygenases which are essential regulators of RNA epigenetics (also called Epitranscritomics), and thus regulate gene expression and cell fate [72]. ALKBH5 also has NANOG mRNA as a target in breast CSCs [71]. Furthermore, ZNF217, an $\mathrm{m}^{6} \mathrm{~A}$ methyl-transferase inhibitor, inhibits the $\mathrm{m}^{6} \mathrm{~A}$ modification of several pluripotency factor mRNAs, including NANOG, KLF4 and SOX2 in breast cancer to promote the CSC-like phenotype and breast cancer metastasis under hypoxic conditions [73]. On other hand, ZNF217 acts as a transcriptional repressor that inhibits FPN expression, leading to intracellular iron retention, increased iron-related cellular activities, and enhanced prostate cancer cell growth [74]. Mechanistic investigations have demonstrated that ZNF217 facilitates the H3K27me3 levels of FPN promoter by cooperating with the histone methyltransferase EZH2 to suppress FPN expression. The hypermethylation of the FPN promoter is also associated with a decreased FPN level in breast cancers [75]. Other iron-related genes are also subject to specific epigenetic modifications. The level of H3K4 methylation, which is associated with a transcriptionally active form, in the HAMP gene promoter coding hepcidin is specifically increased under exposure of BMP-4 or TGF-b [76]. The FPN/hepcidin axis could be a major iron-mediated node for controlling cancer in particular CSCs. In addition, the inhibitors of histone deacetylases (HDAC) enzymes that remove acetyl groups from histones leading to a condensed chromatin state and transcriptional repression, induce FTH expression through the recruitment of NF-Y transcription factor to the FTH promoter [77]. G9a, an H3K9 methyltransferase associated with HDAC1 and YY1, a member of the Krüppel family of transcription factors, forms a silencing multi-molecular complex targeting the repression of the ferroxidase Hephaestin gene, which codes a co-factor of FPN involved in ferric export in breast cancer. Furthermore, a tissue microarray analysis from 75 breast cancer patients revelated that high G9a expression and low hephaestin expression are associated with poor prognosis [78]. Interestingly, iron-chelating agents including deferoxamine (DFO), deferasirox (DFX), and their synthetic derivatives inhibit epigenetic JumonjiC domain-containing histone lysine demethylases (JmjC KDMs) which are $\mathrm{Fe}(\mathrm{II}) / 2$-oxoglutarate-dependent oxygenases that are also involved in transcriptional regulation and DNA repair $[79,80]$. The first demonstration has been performed by Cao et al., showing that DFO induced a significant increase in global histone methylation in colorectal cancer, leading to the dysregulation of many cell growth-related genes [81]. Iron chelation impairs the enzymatic activity of KDM2B, KDM3B, and KDM4C, affecting the demethylation of $\mathrm{H} 3 \mathrm{~K} 9$ and cyclin E1 expression. It was postulated that CSCs arise through epigenetic changes [82]. In particular, specific to the KDM5 family H3K4 histone lysine demethylases, KDM5A (named JARID1A/RPB2) was identified to be overexpressed in drug-resistant cells displaying some CSC-like features [83], and the overexpression of the KDM5B (named JARID1B/PLU1) is a marker for identifying a subpopulation of human melanoma CSC-like cells [84]. Altogether, these findings support the existence of an iron-mediated network/feedback loop that mediates the regulation of both CSC-related 
pathways and epigenetic programs and that is a potential target for novel therapeutic strategies against CSC subpopulations.
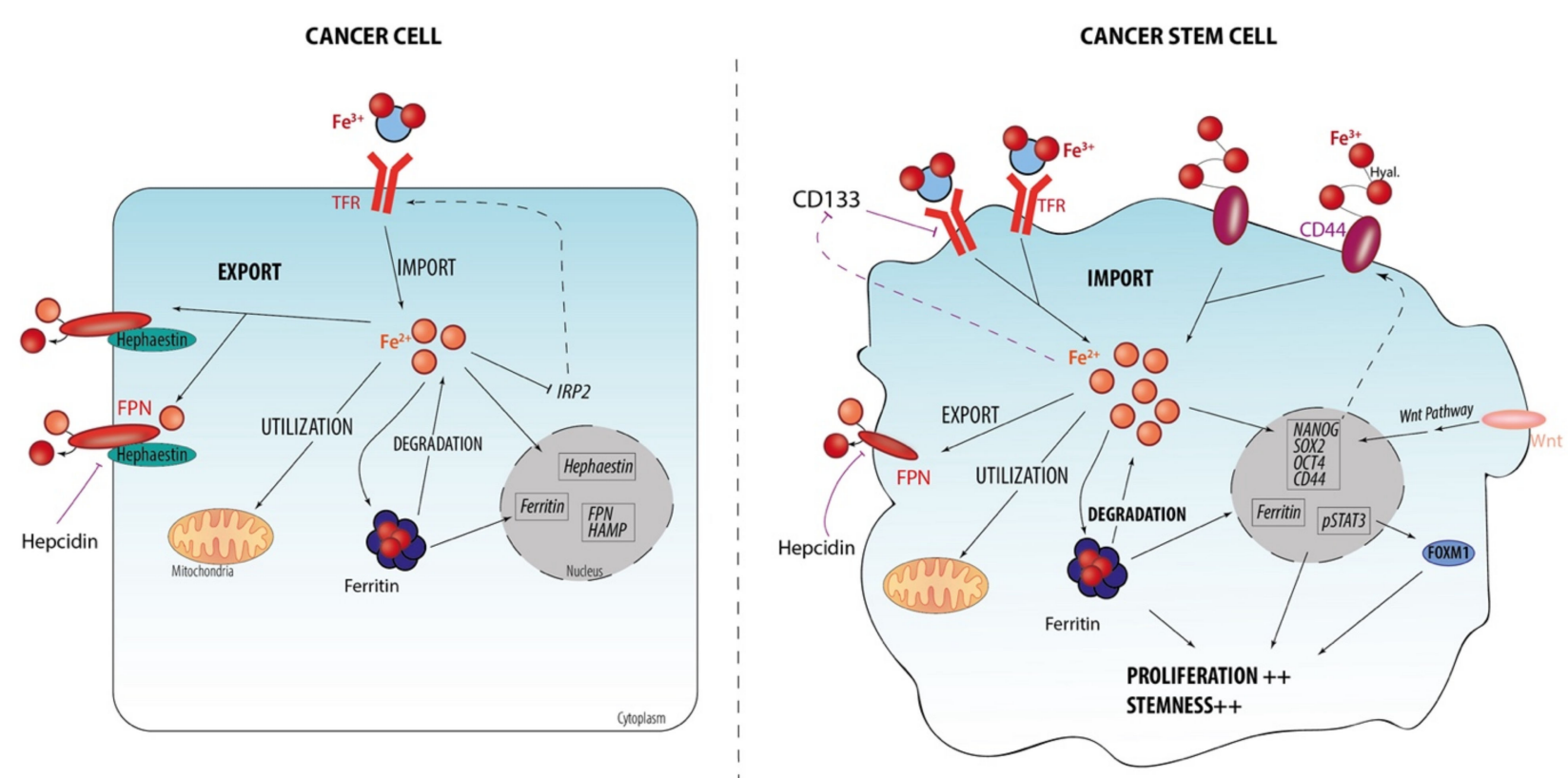

Figure 1. Increased iron metabolism drives CSC expansion and maintenance (compared to non-CSC counterparts). Expression of key proteins involved in iron trafficking are differentially expressed between cancer cells and cancer stem cells. Cancer cells or non-CSCs: low levels of TFR expression (regulated by IRP2, which is itself regulated by the iron status of the cells to maintain iron homeostasis) in charge of iron uptake, and high levels of FPN (regulated by hepcidin, iron master regulator) and/or hephaestin (ferroxidase) expression involved in iron export, collectively lead to low level of intracellular iron. CSCs: High level of CD44 (stem cell marker) via its interaction with iron-bound hyaluronates and TFR via Tf/2Fe ${ }^{3+}$ increase iron uptake, whereas a downregulated FPN level decreases iron efflux. This leads to a higher intracellular iron level, directly supporting the expression of some stem markers (including CD44 or CD133 regulating the endocytosis of TFR/Tf), the Wnt pathway (activator of CD44, SOX2, NANOG, and OCT4 expression), and STAT3-FOXM1 signaling. Thus, this increasing iron metabolism leads to CSC proliferation and supports CSC/stemness behavior. Arrowhead or stop lines indicate promotion/activation or inhibition, respectively.

\section{Ferroptosis, Iron-Driven Cell Death}

\subsection{Iron Accumulation and Lipid Peroxidation: Drivers of Ferroptosis Execution}

Recently, a new type of iron-dependent programmed cell death has been described and named ferroptosis [85]. Many inductors (including erastin, RAS-selective lethal molecule 3 (RSL-3) or pharmacological/clinical drugs such as sorafenib, sulfasalazine, artesunate) were identified before the concept of ferroptosis emerged [86]. Since, the specific inhibitors have been identified, such as liproxstatin-1 (Lip-1), ferrostatin-1 (Fer-1), and vitamin E (VitE), or coenzyme Q10 (CoQ10), as well as their analogs acting as (lipid) ROS scavengers (for reviews, please see [86,87]). Indeed, ferroptosis is morphologically, biochemically, and genetically distinct from other well-known forms of regulated cell death, including apoptosis (caspase-dependent), various forms of necrosis (RIPK1\&3/MLKL dependent), and autophagy (ATGs-dependent) (for recommendations of the nomenclature on cell deaths, please see the review [88]). Morphologically, cells undergoing ferroptosis experience a reduction in cell volume, with intact cell membrane devoid of blebbing; they are lacking chromatin condensation, and have increased mitochondrial membrane density with vestigial cristae and outer mitochondrial membrane rupture $[85,89,90]$. Biochemically, ferroptosis is the result of excessive iron-dependent lipid peroxidation (LOOH) from oxidized polyunsaturated fatty acids (PUFAs)-containing membrane phospholipids. It leads to large molecular damage on proteins, nucleic acids, and lipids [85,91]. Among the 
phospholipids that are oxidized during cell death, arachidonic acid (AA)- or adrenic acid (AdA)-containing diacylated phosphatidylethanolamines (PE) have recently been identified as ferroptotic death signals/precursors by genetic, bioinformatics, and LC-MS/MS lipodomics approaches [92]. Acting as lipid death signals or as the direct executioners of ferroptosis, reactive lipid derivatives can directly or indirectly promote cell death by binding covalently to essential intracellular proteins and thus inactivating them [93]. Oxidizable PUFAS are crucial for the execution of ferroptosis. Thus, the genetic and/or pharmacological inhibition of their incorporation into the cellular membrane, by acyl-CoA synthetase long chain family member 4 (ACSL4) and lysophosphatidylcholine acyltransferase 3 (LPCAT3), or the inhibition of the oxidation of PE-esterified AA and AdA by 15-lipoxygenase (15-LOX, inhibited directly by VitE) protects cells against ferroptosis [94]. In addition to being essential in the enzymatic oxygenation reaction of PUFAs (for example, 15-LOX, an iron-binding enzyme) via the Fenton chemical reaction with hydrogen peroxide $\left(\mathrm{H}_{2} \mathrm{O}_{2}\right)$, excessive level of ferrous ions (from transferrin, ferritin, or again heme) fuels electrondriven lipid peroxidation by the production of hydroxide $\left(\mathrm{OH}^{-}\right)$and hydroxyl radicals $(\cdot \mathrm{OH})$. Iron level regulation is the key actor in ferroptosis execution, as demonstrated by its uptake increased and by the inhibitor action of iron chelators (such deferoxamine (DFO), desferrioxamine mesylate (DFX), and ciclopirox olamine) [95]. Moreover, the addition of exogenous iron (e.g., ferric ammonium citrate, ferric citrate, and iron chloridehexahydrate) sensitizes cells to ferroptosis [85]. In line with this, (Holo-)transferrin (loading for ferric ions $\mathrm{Fe}^{3+}$ ) was also identified as an essential regulator of ferroptosis [96] and transferrin receptor 1 (TFR1/TFRC) and is known to be up-regulated in cells sensitive to ferroptosis [97]. In contrast, the silencing of the iron metabolism master regulator IREB2/IRP2 decreases sensitivity to ferroptosis [85].

\subsection{Antioxidant Systems: The Last Defense before Ferroptosis Execution}

The reduced glutathione (GSH)-dependent enzyme glutathione peroxidase 4 (GPX4), which is directly inhibited by RSL3, has emerged as the main endogenous inhibitor of ferroptosis due to its ability to limit lipid peroxidation by catalyzing the GSH-dependent reduction of lipid hydroperoxides to lipid alcohols. Indeed, genetics studies on gpx4 knockout animals have probed the evidence of the role of GPX4 as the most downstream regulator of ferroptosis (for a review, please see [98]). If systemic Gpx4 knockout mice display embryonic lethality [99], the tissue-specific conditional ablation of Gpx4 will lead to different pathologic issues, including acute renal and hepatic injury, neurodegeneration, and defective immunity to infection, suggesting the role of GPX4 in development and tissue homeostasis. More importantly, ferroptosis-specific inhibitors (including Fer-1, Lip-1, and VitE) could prevent tissue damage, underlining the contribution of ferroptosis to several types of tissue demise. Furthermore, ferroptosis inhibitors could also prevent tissue damage in models of ischemia/reperfusion injury in the kidneys [100,101], liver [86,90], and heart [96], proving the pathophysiological relevance of ferroptosis. As its name indicates, GPX4 activity is affected by dysfunctions in cysteine metabolism, leading to the depletion of glutathione or GSH levels [102]. Cystine is imported into cells in exchange for glutamate by the $\mathrm{X}_{\mathrm{c}}{ }^{-}$system (SLC7A11(xCT)/SLC3A2 complex), then reduced in the cysteine required for the synthesis of GSH [103]. Among the ferroptotic inducers, erastin, sorafenib, sulfasalazine, and L-glutamate suppress cysteine transport [104]. Other pathways involved in the cysteine biosynthesis level and in the biosynthesis of GPX4 have been identified to regulate ferroptosis, including the trans-sulfuration pathway [105] and mevalonate pathway [106], respectively. More recently, connected with the mevalonate pathway, ferroptosis suppressor protein 1 (FSP1), previously known as apoptosis-inducing factor mitochondrial-associated 2 (AIFM2), was identified as a ferroptosis resistance factor acting independently of GPX4/glutathione activity [107]. By reducing CoQ10, a byproduct of the mevalonate pathway, to CoQ10-H2 with NADPH, FSP1 inhibits the propagation of PL peroxidation. Figure 2 illustrates the molecular interactions involved in the induction and regulation of ferroptosis. 


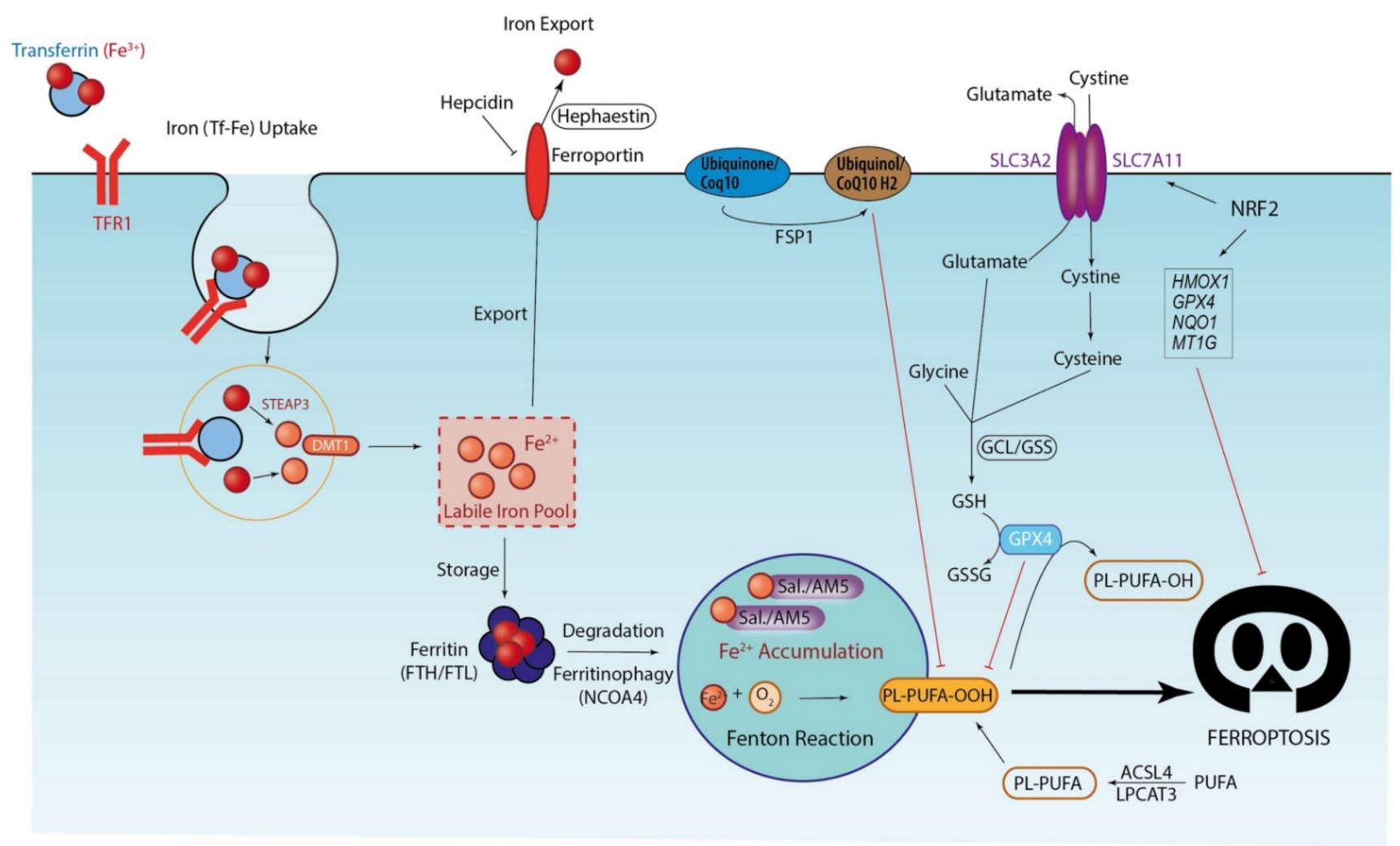

Figure 2. Molecular interactions involved in the induction and regulation of ferroptosis. Decisive characteristics of ferroptosis resulting from phospholipid peroxidation $(\mathrm{LOOH})$ are: $(1)$ its dependence on iron, under the Fenton reaction $\left(\mathrm{Fe}^{2+}+\mathrm{H}_{2} \mathrm{O}_{2} \rightarrow \mathrm{Fe}^{3+}+\mathrm{OH}+\mathrm{OH}^{-}\right)$, which can be caused by: (i) the increased expression of key players for iron uptake, including iron-binding transferrin receptors (TfR1/TFRC), or even DMT1 or STEAP3 that directly bind iron; (ii) the degradation of ferritin (FTH/FTL complex), which is the iron-storage protein, involving ferritinophagy, an NCOA4dependent autophagic process to release iron in the lysosome; (iii) lysosomal iron sequestration, as induced by Sal./AM5; and iv) the hepcidin-mediated inhibition of ferroportin expression, which is involved by the export of iron and thus promotes iron retention. (2) Disturbances in the GSH/GPX4 axis that ensures the redox balance; or in the same order, disturbances in the level of CoQ10 (a byproduct of the mevalonate pathway) with its FSP-1 reductase that were recently found to prevent the peroxidation of membrane lipids. ACSL4 and LPCAT3, which are involved in the esterification of PUFA in membrane phospholipids (PL-PUFA), are key actors in sensitivity to ferroptosis. NRF2, the master antioxidant regulator, is also able to prevent ferroptosis by activating the expression of a large number of genes encoding ferroptosis inhibitors including NQO1, HMOX1, FTH, GPX4, system $\mathrm{X}_{\mathrm{c}}^{-}{ }^{-}$/SLC7A11, the GCL/GSS enzymes involved in the GSH synthesis, and lastly MT1 G. Arrowhead or stop lines indicate promotion/activation or inhibition, respectively.

\section{Autophagy and Ferroptosis Regulation}

\subsection{Ferritinophagy: Drivers of Ferroptosis Initiation}

The activation of ferritinophagy, a newly defined selective form of macroautophagy required for the specific lysosomal degradation of ferritin [108], the main cellular iron-storage protein, seems to occur during the early initiation stage of ferroptosis. Indeed, although it occurs to maintain the iron balance, recent discoveries have highlighted the importance of ferritinophagy with transferrin trafficking as critical determinants of ferroptosis sensitivity via an increase in the labile iron pool promoting ROS generation. As described above, ferritin is able to store up to 4500 iron atoms in a 24-subunit macromolecular complex formed by ferritin light and heavy chains (FTL and FTH, respectively), and its specific lysosomal degradation releases iron and supplies the cell's iron need. However, excess iron fuels the Fenton reaction, leading to the production of highly toxic hydroxyl radicals. When ferritinophagy occurs, nuclear receptor coactivator 4 (NCOA4) was recently identified as a specific autophagic cargo receptor that selectively recognizes FTH via the C-terminal domain of NCOA4, binding a conserved surface arginine (R23) on FTH [109]. 
The first demonstration that ferroptosis is a selective autophagic cell death process was performed by Gao et al. using the ferroptosis inducers erastin and cystine starvation [110]. By using RNAi screening coupled with subsequent genetic analysis, they were able to identify multiple autophagy-related genes as positive regulators of ferroptosis. Consistently, the inhibition of ferritinophagy by the blockage of autophagy (with bafilomycin A1 and chloroquine) or knockdown of NCOA4 (as well as ATG3/5/7/13) represses the accumulation of ferroptosis-associated cellular labile iron and lipid ROS and ultimately ferroptotic cell death $[110,111]$. These findings can be extended to other cancer cell lines (including human fibrosarcoma, human pancreatic carcinoma, leukemia, head and neck carcinoma) and to other ferroptotic inducers (including dihydroartemisinin (DHA)) [110-113]. In particular, DHA, a semi-synthetic derivative of artemisinin anti-malarial drug, accelerates ferritinophagy through the AMP-activated protein kinase (AMPK)/mammalian target of rapamycin (mTOR)/p70S6k signaling pathway to trigger ferroptosis in acute myeloid leukemia cells [112]. Notably, we demonstrated a newly identified mechanism in which the salinomycin/ironomycin-mediated iron sequestration in lysosomes promotes ferritin degradation and the Fenton reaction, leading to the toxic lipid ROS and ultimately and preferentially to ferroptosis in breast CSCs [39]. We described that a "vicious circle" occurs, leading to iron-dependent cell death, which we may call a "deathloop" (Figure 2). However, the role of autophagy remains to be clarified.

\subsection{Autophagy: A Dual Role in Ferroptosis Execution}

Interestingly, autophagy is able to selectively target other ferroptosis-related actors. Many ferroptotic inducers including erastin, RSL3, FIN56, and sulfasalazine promote the degradation of GPX4 protein which is the only enzyme capable of inhibiting lipid peroxidation by reducing phospholipid hydroperoxide $[106,114]$. Interestingly, GPX4 is targeted by HSP90/LAMP2A- and HSPA8/HSC70-mediated autophagy (also known as chaperonmediated autophagy, CMA) and is thus involved in the execution of ferroptosis. However, HSPA5 increases GPX4 protein stabilization [114] supporting the role of HSPs in the regulation of ferroptosis. More importantly, this finding extended our knowledge of the role of other forms of autophagy in the regulation of ferroptosis [115]. In particular, lipophagy, the selective autophagic degradation of lipid droplets (LDs) that are complex spherical organelles stocking neutral lipids, leads to the release of free fatty acids and promotes lipid peroxidation in ferroptosis [116,117]. The knockdown of the LD cargo receptor $R A B-7 A$ (a member of the RAS oncogene family) or ATG5 also limits lipid peroxidation-mediated ferroptosis [117,118]. In line with lipid metabolism, hypoxia inducible factor 1 subunit alpha (HIF1A), one of major transcriptional factors regulating hypoxic response, is able to regulate negatively RSL-3/FIN56-induced ferroptosis through the upregulation of fatty acid binding protein 3/7 (FABP3/7), which is involved in fatty acid uptake and lipid storage [119]. Interestingly, the SQSTM1/p62-dependent autophagic degradation of the key circadian clock protein/regulator ARNTL (newly defined as "clockophagy") leads to the EGLN2/PHD1 (egl nine homolog 2/hypoxia-inducible factor prolyl hydroxylase 1)-mediated downregulation of HIF1A, thus promoting ferroptosis [119]. More recently, Song et al., demonstrated that AMPK-mediated Beclin-1 phosphorylation promotes erastin/SAS-induced ferroptosis by directly blocking system $\mathrm{X}_{\mathrm{c}}{ }^{-}$/SLC7A11 activity and leading to GSH depletion [120]. Accordingly, the Beclin-1 activator peptide TAT-BECN1 and the RNA-binding protein ELAV-like RNA-binding protein 1 (ELAVL1) increasing BECN1 mRNA stability also promote the SLC7A11/system $X_{c}{ }^{-}$inhibitor-mediated ferroptosis [120,121]. It is thought that HMGB1, more widely known as a danger signal in immune responses, positively regulates erastin-induced ferroptosis in leukemia cells through the mitogen-activated protein kinase (MAPK/JNK/p38)-mediated upregulation of TFRC expression [122]. Nevertheless, endogenous HMGB1 can presumably also act through the activation of autophagy, being a BECN1-binding protein or an activator of the BECN1/PIK3C3 complex involved in the induction of autophagosome formation [123,124]. Additionally, the intracellular iron exporter FPN is now identified as a substrate for autophagic elimination, and its 
degradation by SQSTM1/p62 promotes erastin/RSL3-mediated ferroptosis in vitro and in xenograft tumor mouse models [125]. Importantly, inducing the autophagic degradation of FPN overcomes ferroptosis resistance. In addition, the inhibition of mitochondrial iron accumulation by the upregulation of the mitochondrial iron exporter CDGSH iron sulfur domain 1 (CISD1, also termed mitoNEET) [126] and the increase in mitochondrial ferritin (FtMt) [127] inhibits ferroptosis suggesting that mitophagy, the selective autophagic degradation of mitochondria, can promote/accelerate ferroptotic cancer cell death. Nevertheless, by targeting the SQSTM1/p62-mediated degradation of KEAP-1, autophagy induces the stabilization of NFE2L2/NRF2 (nuclear factor (erythroid-derived 2)-like 2) protein and its transcriptional activity, which mainly mediates the antioxidant responses, thus preventing erastin and sorafenib-induced ferroptosis in hepatocellular carcinoma cells [128]. NFE2L2/NRF2 transcription factor actives the expression of a large number of genes encoding ferroptosis inhibitors including NQO1 (NAD[P]H quinone dehydrogenase 1), HMOX1 (heme oxygenase 1), FTH (ferritin heavy chain), GPX4, system $X_{c}{ }^{-} /$SLC7A11, and lastly MT1 G (metallothionein 1G) [128-132]. Interestingly, the overexpression of GPX4, consistent with its anti-oxidant function, has been shown to inhibit ROS-mediated autophagy to prevent immunogenic cell death, another regulated-cell death modality [133]. Accordingly, some studies have recently revealed the interplay between mTORC1, the master negative regulator of autophagy, and GPX4 signaling, suggesting the existence of a feedback loop between autophagy and ferroptosis [134,135]. Altogether, these findings highlight the ability of some key proteins of autophagy to directly or indirectly act on key factors initiating or regulating ferroptosis, and thus positively or negatively modulate the sensitivity to ferroptosis.

\section{Therapeutic Strategies to Target Ferroptosis in CSCs/Targeting Ferroptosis in CSCs \\ 5.1. Through Manipulating Tumor-Suppressor p53}

At present, accumulating evidence supports the importance of ferroptosis both in the suppression of tumorigenesis and in cancer therapies (for a review, please see [136]). The best examples are studies highlighting the role of the tumor suppressor p53 (also called the "guardian" of genome stability) in the maintenance of cell/organism integrity by regulating ferroptosis through its transcriptional activity or a transcription-independent mechanism $[137,138]$. On one hand, p53 promotes ferroptosis through the inhibition of system $\mathrm{X}_{\mathrm{c}}{ }^{-}$/SLC7A11 expression [139] or the promotion of SAT1 (spermidine/spermine N1-acetyltransferase 1), thereby activating 15-LOX (arachidonate lipoxygenase) expression [140], or again through glutaminase 2 (GLS2) expression involved in glutaminolysis [141]. On the other hand, p53 suppress ferroptosis by sequestering directly dipeptidylpeptidase 4 (DPP4) in the nucleus and inhibiting DPP4-dependent lipid peroxidation at the plasma membrane [142]. Interestingly, the expression of DPP4/CD26 defines a cancer cell subpopulation displaying CSC-like features and correlated with poor prognosis in human colorectal cancer $[143,144]$, suggesting that this population could be effectively targeted by ferroptosis inducers. More recently, iPLA2b (a member of the calcium-independent phospholipase A2), newly identified as a p53-target gene, acts as a major suppressor of p53-driven ferroptosis in a GPX4-independent manner under ROS-induced stress in numerous cancer cell lines [145]. iPLA2b mediates the detoxification of phospholipids by releasing oxidized fatty acids and is overexpressed in many human cancers, including kidney renal clear cell carcinoma and acute myeloid leukemia [145]. Notably, the inhibition of endogenous iPLA2b promotes p53-dependent tumor suppression in xenograft mouse models [145]. This finding suggests that iPLA2b is a promising therapeutic target for activating ferroptosis-mediated tumor suppression without serious toxicity concerns. In addition of their role in lipid metabolism, the inhibition of phospholipase A2 could thus more efficiently trigger the cell death of CSCs [146]. Altogether, p53 exerts its effect in a highly context-dependent manner on the regulation of lipid peroxidation in ferroptosis. Nevertheless, p53 could also regulate ferroptotic cancer cell death via its action on the regulation of autophagy. Moreover, recent works have highlighted that Eprene- 
tapopt (APR-246, PRIMA-1 ${ }^{\mathrm{MET}}$ ), known as a mutant-p53 reactivator, is also able to induce p53-independent ferroptosis by GSH depletion through its capacity to conjugate to free cysteine [147] in several human cancers, including AML [148] and esophageal cancer [149]. Interestingly, APR-246, which is already used in clinical trials [149], in combination with ferroptosis inducers have a synergistic anti-leukemic activity in vivo, opening new therapeutic opportunities in AML [148]. Notably, cysteine deprivation targets leukemia stem cells more efficiently, with no detectable effect on normal hematopoietic stem/progenitor cells [150]. Therefore, the induction of ferroptosis creates a new therapeutic strategy to target CSCs in different histological types of cancer, especially for drug-resistant tumors, with a low toxicity.

\subsection{Through the Use of Ferroptosis Inducers Now Available}

Indeed, through our recent work and other studies, iron homeostasis is now recognized as one of the hallmarks of CSCs in numerous/different human cancers, including breast cancer, ovarian cancer, prostate cancer, lung cancer, cholangiocarcinoma and glioblastoma. In this context, ferroptosis inducers (such as small molecules erastin and RSL-3/5, initially developed to selectively target tumor cells bearing oncogenic RAS and chemotherapeutic drug resistance) now existing as well as other yet-to-be-developed irondriven cell death inducers, have therapeutic potential in anti-CSC therapy. In addition, many clinical drugs (including sorafenib, sulfasalazine, FIN56, FINO2, artesunate, and dihydroartemisinin) are even available for use in ferroptosis-mediated cancer therapies. However, they have not been tested in CSCs yet. Their actions are summarized in Table 2. We carried the first demonstration highlighting that the anti-CSC compound salinomycin and its synthetic analog ironomycin, target the cell death of breast CSCs more efficiently and specifically both in vitro and in vivo by ferroptosis in sequestering iron in the lysosome $[39,40]$. Furthermore, the inhibition of other negative regulators of ferroptosis, such as CD44 or newly identified heat shock protein b-1 (HSPB1), also has great potential in this anti-cancer therapeutic strategy. Indeed, the highly used CSC marker CD44 (specially $\mathrm{CD} 44 \mathrm{v}$ isoforms) has been described to prevent ferroptosis by promoting GSH synthesis through the stabilization of the $\mathrm{xCT} / \mathrm{SLC7A11}$ subunit of the cystine importer system $\mathrm{X}_{\mathrm{c}}{ }^{-}$ at the surface membrane in gastrointestinal cancer stem-like cells [151]. Therapy targeted to the CD44v-xCT system could thus impair the GSH-mediated ROS defense ability of CSCs and lead to the depletion of CSCs [152,153]. Heat-shock protein beta-1 (HSPB1) inhibits erastin-induced ferroptosis by affecting iron uptake and subsequent lipid peroxidation [154]. Interestingly, several studies have previously shown that HSPB1 is required for selective autophagy, including mitophagy and lipophagy $[123,155,156]$. In addition, linked to increased lipid metabolism by CSCs, targeting key players of fatty acids metabolism may prove a promising anti-CSC strategy to better trigger ferroptosis [146]. For example, the inhibition of fatty acid oxidation by Etomoxir impairs CSC self-renewal and tumorigenicity in a hepatocellular carcinoma (HCC) context and sensitizes HCC CSCs to sorafenib, which is a broadly used chemotherapy drug against HCC [157]. Compared to iron chelation strategies, the preferential iron loading in CSCs, such as through aminoferrocene-based therapies [158-161], may also be more therapeutically useful for enhancing their sensitivity to ferroptosis. More recently, Gao J. et al., performed an elegant demonstration of a new cancer therapy named gene-interfered-ferroptosis therapy (GIFT) by combining iron nanoparticles with cancer-specific gene interference, here targeting two iron metabolic genes (FPN and LCN2) both in vitro and in vivo [162]. Significant ferroptosis was induced in a wide variety of cancer cells, with only very little effect on normal cells. This cancer therapy based on gene interference-enhanced ferroptosis also resulted in a significant tumor growth inhibition and durable cure in mice, encouraging new efforts to be made in the study of ferroptosis and iron dysregulation in CSCs. 
Table 2. Ferroptosis inducers in different cancers. Most ferroptosis inducers are classified into 2 categories on the basis of their mechanism of action: Class 1 inducer: inhibition of system $\mathrm{Xc}^{-}$ leading to GSH depletion; Class 2 inducer: inhibition of GPX4 activity leading to lipid peroxidation.

\begin{tabular}{|c|c|c|c|}
\hline Name & Class/Action & Cancer & Ref \\
\hline $\begin{array}{c}\text { Erastin } \\
\text { and its derivatives } \\
\text { (better stability): } \\
\text { Aldehyde erastin } \\
\text { Piperazine } \\
\text { Morpholine erastin II }\end{array}$ & $\begin{array}{c}\text { Targets the mitochondrial } \\
\text { voltage-dependent anion } \\
\text { channel } 2 / 3 \text { (VDAC2/3); } \\
\text { Class I inducer through } \\
\text { the binding of SLC7A5, a } \\
\text { subunit of system } \\
\text { Xc }^{-} / \text {induces of } \\
\text { Beclin1-SCL7A11 complex } \\
\text { formation/inhibits cystine } \\
\text { uptake leading to GSH } \\
\text { depletion/induces also the } \\
\text { GPX4 protein degradation }\end{array}$ & $\begin{array}{l}\text { Kras-mutant tumor cells, } \\
\text { lung, leukemia, CRC }\end{array}$ & {$[73,118,163]$} \\
\hline Sulfasalazine (SAS) & $\begin{array}{l}\text { Class I inducer/Induces } \\
\text { Beclin1-SCL7A11 complex } \\
\text { formation/inhibits cystine } \\
\text { uptake leading to GSH } \\
\text { depletion }\end{array}$ & $\begin{array}{c}\text { Lymphoma, SCLC, } \\
\text { prostate cancer, breast } \\
\text { cancer, glioblastoma, } \\
\text { combined with dyclonine, } \\
\text { targets ALDH3A1 } 1^{+} \\
\text {tumors cells in head and } \\
\text { neck squamous cell } \\
\text { carcinoma and in gastric } \\
\text { tumors, leukemia, } \\
\text { pancreatic cancer }\end{array}$ & {$[85,163-168]$} \\
\hline Sorafenib & $\begin{array}{l}\text { Class I inducer/inhibits } \\
\text { the activity of system } \mathrm{Xc}^{-}\end{array}$ & $\begin{array}{c}\text { Liver, kidney, lung or } \\
\text { pancreatic derived cell } \\
\text { lines, AML, HCC, } \\
\text { neuroblastoma, NSCLC, } \\
\text { RCC }\end{array}$ & {$[95,169]$} \\
\hline Tat-beclin1 & $\begin{array}{l}\text { Enhances erastin } \\
\text { anti-cancer activity/direct } \\
\text { inhibitor of the activity of } \\
\text { system } \mathrm{Xc}^{-} / \text {leads to lipid } \\
\text { peroxidation }\end{array}$ & $\begin{array}{l}\text { Colon, pancreas, lung } \\
\text { (NSCLC), cervical }\end{array}$ & [120] \\
\hline $\begin{array}{c}\text { Lanperisone } \\
\text { (FDA-approved drug) }\end{array}$ & $\begin{array}{l}\text { Class I inducer/inhibits } \\
\text { cystine uptake leading to } \\
\text { GSH depletion }\end{array}$ & Kras-mutant tumor cells & [170] \\
\hline RSL3/5 & $\begin{array}{l}\text { Class } 2 \text { inducer/binds } \\
\text { GPX4 to inhibit its } \\
\text { enzymatic } \\
\text { activity/induces also the } \\
\text { GPX4 protein degradation }\end{array}$ & $\begin{array}{l}\text { Kras-mutant tumor cells; } \\
\text { AML cells, Head and neck } \\
\text { cancer, Colorectal cancer }\end{array}$ & {$[97,106,113,171-173]$} \\
\hline $\begin{array}{l}\text { FIN(ferroptosis } \\
\text { inducing }) 56\end{array}$ & $\begin{array}{c}\text { Class2 inducer, } \\
\text { downregulates GPX4 } \\
\text { expression at mRNA } \\
\text { level/targets GPX4 } \\
\text { degradation/causes } \\
\text { depletion of } \\
\text { mevalonate-derived } \\
\text { coenzyme Q10 (CoQ10) }\end{array}$ & $\begin{array}{l}\text { Osteosarcoma, lung } \\
\text { adenocarcinoma, } \\
\text { fibrosarcoma }\end{array}$ & [106] \\
\hline $\begin{array}{c}\text { FINO2 (endoperoxide- } \\
\text { containing } \\
\text { 1,2-dioxolane) }\end{array}$ & $\begin{array}{c}\text { Class } 2 \text { inducer/represses } \\
\text { indirectly the enzymatic } \\
\text { function of GPX4 leading } \\
\text { widespread lipid } \\
\text { peroxidation/is able to } \\
\text { oxidize ferrous iron } \\
\text { directly/can also oxidize } \\
\text { lipids, providing another } \\
\text { source of lipid peroxides }\end{array}$ & $\begin{array}{l}\text { NIH60, a range of cancer } \\
\text { cell lines from different } \\
\text { tissues, engineered cancer } \\
\text { cells such as RCC cells and } \\
\text { fibrosarcoma cells }\end{array}$ & {$[174,175]$} \\
\hline $\begin{array}{c}\text { Artesunate (artemisinin } \\
\text { derivative, anti-malaria } \\
\text { drug) }\end{array}$ & $\begin{array}{l}\text { Targets iron/induces } \\
\text { ferritin degradation } \\
\text { leading to the lysosomal } \\
\text { iron release and Fenton } \\
\text { reaction with ROS }\end{array}$ & $\begin{array}{c}\text { mutationaly-active Kras } \\
\text { pancreatic ductal } \\
\text { adenocarcinoma cell lines, } \\
\text { lymphoma }\end{array}$ & [176-179] \\
\hline
\end{tabular}


Table 2. Cont.

\begin{tabular}{|c|c|c|c|}
\hline Name & Class/Action & Cancer & Ref \\
\hline $\begin{array}{l}\text { Dihydroartemisinin } \\
\text { (DHA, semi-synthetic } \\
\text { artemisinin derivative) }\end{array}$ & $\begin{array}{c}\text { Targets iron/inducs the } \\
\text { autophagy-dependent } \\
\text { degradation of ferritin by } \\
\text { regulating the activity of } \\
\text { the } \\
\text { AMPK/mTOR/p70S6K } \\
\text { pathway }\end{array}$ & $\begin{array}{l}\text { Leukemia, glioma, head } \\
\text { and neck cancer; }\end{array}$ & {$[112,180]$} \\
\hline $\begin{array}{l}\text { BSO (Buthionine } \\
\text { sulfoximine) }\end{array}$ & $\begin{array}{c}\text { Targets GCLC; prevents } \\
\text { GSH synthesis; }\end{array}$ & $\begin{array}{l}\text { HCC, Kras-mutant tumor } \\
\text { cells SCLC cancer }\end{array}$ & {$[128,172,181]$} \\
\hline Siramesine and lapatinib & $\begin{array}{l}\text { Targets iron, decreases the } \\
\text { expression of FPN and } \\
\text { Ferritin and increases iron } \\
\text { uptake through } \\
\text { upregulation of TRFC; }\end{array}$ & Breast cancer cells & {$[182,183]$} \\
\hline $\begin{array}{l}\text { Salinomycine and its } \\
\text { synthetic derivate } \\
\text { Ironomycin }\end{array}$ & $\begin{array}{l}\text { Sequesters lysosomal iron } \\
\text { leading to cytoplasmic } \\
\text { iron depletion/increases } \\
\text { iron uptake through the } \\
\text { up-expression of IRP2 and } \\
\text { TFRC, along with the } \\
\text { accelerated lysosomal } \\
\text { degradation of ferritin }\end{array}$ & $\begin{array}{c}\text { Breast cancer stem cells, } \\
\text { ovarian cancer }\end{array}$ & {$[39,40,184]$} \\
\hline Cyst(e)inase & $\begin{array}{l}\text { Targets enzymatic } \\
\text { degradation of } \\
\text { cystine/cysteine, } \\
\text { restricting its availability } \\
\text { to cancer cells and } \\
\text { triggering ferroptosis }\end{array}$ & $\begin{array}{l}\text { Breast cancer, chronic } \\
\text { lymphocytic leukemia, } \\
\text { melanoma, pancreatic } \\
\text { cancer, prostate cancer }\end{array}$ & [185-187] \\
\hline $\begin{array}{l}\text { Statins (Fluvastatin, } \\
\text { Pravastin, lovastatin and } \\
\text { simvastatin), inhibitors } \\
\text { of HMGCR (HMG-CoA } \\
\text { reductase), a } \\
\text { rate-limiting enzyme in } \\
\text { the mevalonate pathway }\end{array}$ & $\begin{array}{l}\text { Are able to inhibit the } \\
\text { biosynthesis of } \\
\text { selenoproteins including } \\
\text { GPX4 and CoQ10 }\end{array}$ & $\begin{array}{c}\text { Breast cancer, HCC, AML, } \\
\text { MM; }\end{array}$ & [188-191] \\
\hline $\begin{array}{c}\text { Eprenetapopt } \\
\text { (APR-017/PRIMA-1, } \\
\text { APR-246/PRIMA-1 }\end{array}$ & $\begin{array}{l}\text { Mutant- } p 53 \text { reactivators, } \\
\text { has also the ability to } \\
\text { conjugate free cysteine } \\
\text { leading to GSH depletion } \\
\text { and interferes with } \\
\text { iron-sulfur cluster } \\
\text { biogenesis }\end{array}$ & AML & [148] \\
\hline $\begin{array}{l}\text { Ferumoxytol (Feraheme, } \\
\text { FDA-approved iron } \\
\text { oxide nanoparticle) }\end{array}$ & $\begin{array}{l}\text { Targets iron, fuels Fenton } \\
\text { reaction leading to } \\
\text { harmful production of } \\
\text { ROS; }\end{array}$ & Leukemia cells & [160] \\
\hline $\begin{array}{l}\text { Iron salophen complexes } \\
\text { (chemicaly-engineered } \\
\text { transition-metal } \\
\text { complexes) }\end{array}$ & $\begin{array}{l}\text { Generate lipid ROS } \\
\text { leading to ferroptosis }\end{array}$ & $\begin{array}{l}\text { Leukemia, neuroblastoma } \\
\text { cell lines }\end{array}$ & [161] \\
\hline Fenugreek (trigonelline) & $\begin{array}{c}\text { Inhibits NRF2 leading the } \\
\text { blockage of MT-1G } \\
\text { expression, and GSH } \\
\text { depletion }\end{array}$ & $\begin{array}{l}\text { HCC cells, head and neck } \\
\text { cancer cells }\end{array}$ & [128] \\
\hline
\end{tabular}

AML, Acute Myeloid Leukemia; CRC, Colorectal cancer; HCC, Hepatocellular Carcinoma; MM, Multiple Myeloma; (N)SCLC, (Non)-Small-Cell Lung Cancer; RCC, Renal Cell Cancer.

\section{Conclusions and Perspectives}

In summary, the accumulation of intracellular iron and iron addiction, inter alia, for their maintenance and expression of stem cells markers are newly identified hallmarks of CSCs. Iron therefore represents a vulnerability or Achilles' heel of CSCs that could be therapeutically exploitable for more efficiently targeting cell death in anti-CSC therapies. On one hand, iron deprivation mediated by iron chelation strategies could initially constitute a first potential therapeutic approach. Indeed, iron chelators may interfere with some CSC-related markers/actors or signaling pathways and affect CSC expansion or 
ultimately induce cell death by apoptosis. However, this therapeutic strategy has shown its limits in hematological cancers even if the patients also suffer chronic iron overload leading to cardiac, hepatic, or endocrinal damage. In the case of other histological types of cancer, patients display more anemia, excluding the use of chelator molecules. On the other hand, manipulating iron accumulation via the induction of ferroptosis can constitute an effective strategy to target CSCs. Accordingly, CSCs rely on iron until they "die for" it. Indeed, CSCs have shown to be far more susceptible to ferroptosis than to apoptosis, thus initiating the development of new therapeutic perspectives. Furthermore, some ferroptosis chemical inducers are now available, including various FDA-approved drugs. In addition, triggering ferroptosis can synergize or enhance the anti-cancer capacity of conventional therapies, including chemotherapies and radiotherapies, by overcoming tumor resistance. Ferroptosis is also often described as autophagy-mediated cell death, indicating that the activation of autophagy may be involved in both the occurrence and regulation of ferroptosis. Indeed, autophagy (degradative pathways under its different forms) selectively targets various key actors of ferroptosis. However, autophagy also plays a dual role (promotor versus repressor) in ferroptosis that is dependent on many conditions. In particular, lipid metabolism is connected with both autophagy, through its impact on autophagosome membrane formation, and ferroptosis, through lipid peroxidation, which may play a critical role in the regulation of ferroptosis as part of a feedback loop. Thus, some molecular mechanisms in the regulation of ferroptosis remain largely unknown. In addition, our knowledge about the mechanisms of iron metabolism dysregulation, particularly in CSCs, must be improved in order to cure cancer with a low toxicity and develop personalized cancer therapies targeting CSCs through ferroptosis.

Author Contributions: A.H. and M.M. have contributed equally to the writing process of this manuscript. E.C., M.M. and A.H. drafted the manuscript. E.C., R.E.H., L.D.S. and C.G. discussed, helped to design all figures and contributed to writing the review. All authors have read and agreed to the published version of the manuscript.

Funding: This study was supported in part by grants from INSERM, Université Paris DescartesSorbonne Paris Cité and la Ligue Contre le Cancer-Ile de France.

Institutional Review Board Statement: Not applicable.

Informed Consent Statement: Not applicable.

Data Availability Statement: Not applicable.

Acknowledgments: We thank INSERM and la Ligue Contre le Cancer-Ile de France for generous funding.

Conflicts of Interest: The authors declare no conflict of interest.

\begin{abstract}
Abbreviations
FPN, Ferroportin; HAMP, Hepcidin Antimicrobial Peptide; Hyal., Hyaluronate; IRP2, Iron-Regulatory Protein 2; OCT4, Octamer Binding Transcription Factor; SOX2, SRY-Box Transcription Factor 2; Tf, Transferrin; TFR, Transferrin Receptor; ACSL4, Acyl-CoA synthetase long chain family member 4; CoQ10, coenzyme Q10/Ubiquinone-10; DMT1, divalent metal transporter 1/Nramp2; FSP1, ferroptosis-suppressor-protein 1; FTH, ferritin heavy chain; FTL, ferritin light chain; GCL, glutamatecysteine ligase; GPX4, glutathione peroxidase 4; GSH, Glutathione; GSS, Glutathione synthetase; HMOX1, heme oxygenase 1; LIP, Labile iron pool; LPCAT3, lysophosphatidylcholine acyltransferase; MT1 G, metallothionein 1G; NCOA4, Nuclear receptor coactivator 4; NQO1, NAD[P]H quinone dehydrogenase 1; NFE2L2/NRF2, nuclear factor (erythroid-derived 2)-like 2; PL, Phospholipids; PUFA, polyunsaturated fatty acids; ROS, Reactive Oxygen Species; Sal., Salinomycin; SLC3A2/SLC7A11(xCT), glutamate/cystine anti-transporter; STEAP3, Six-Transmembrane Epithelial Antigen Of Prostate 3 Metalloreductase; Tf, Transferrin; TFR1/TFRC, Transferrin receptor 1.
\end{abstract}




\section{References}

1. Torti, S.V.; Torti, F.M. Iron: The cancer connection. Mol. Asp. Med. 2020, 75, 100860. [CrossRef]

2. Zhang, C.; Zhang, F. Iron homeostasis and tumorigenesis: Molecular mechanisms and therapeutic opportunities. Protein Cell 2015, 6, 88-100. [CrossRef]

3. Muñoz, M.; Gómez-Ramírez, S.; Martín-Montañez, E.; Auerbach, M. Perioperative anemia management in colorectal cancer patients: A pragmatic approach. World J. Gastroenterol. 2014, 20, 1972-1985. [CrossRef]

4. Pantopoulos, K.; Porwal, S.K.; Tartakoff, A.; Devireddy, L. Mechanisms of mammalian iron homeostasis. Biochemistry 2012, 51, 5705-5724. [CrossRef]

5. Ganz, T.; Nemeth, E. Hepcidin and iron homeostasis. Biochim. Biophys. Acta 2012, 1823, 1434-1443. [CrossRef]

6. Manz, D.H.; Blanchette, N.L.; Paul, B.T.; Torti, F.M.; Torti, S.V. Iron and cancer: Recent insights. Ann. N. Y. Acad. Sci. 2016, 1368, 149-161. [CrossRef] [PubMed]

7. Muckenthaler, M.U.; Rivella, S.; Hentze, M.W.; Galy, B. A Red Carpet for Iron Metabolism. Cell 2017, 168, 344-361. [CrossRef]

8. Walcher, L.; Kistenmacher, A.-K.; Suo, H.; Kitte, R.; Dluczek, S.; Strauß, A.; Blaudszun, A.-R.; Yevsa, T.; Fricke, S.; Kossatz-Boehlert, U. Cancer Stem Cells-Origins and Biomarkers: Perspectives for Targeted Personalized Therapies. Front. Immunol. 2020, 11, 1280. [CrossRef] [PubMed]

9. Marquardt, S.; Solanki, M.; Spitschak, A.; Vera, J.; Pützer, B.M. Emerging functional markers for cancer stem cell-based therapies: Understanding signaling networks for targeting metastasis. Semin. Cancer Biol. 2018, 53, 90-109. [CrossRef]

10. Müller, S.; Sindikubwabo, F.; Cañeque, T.; Lafon, A.; Versini, A.; Lombard, B.; Loew, D.; Wu, T.-D.; Ginestier, C.; Charafe-Jauffret, E.; et al . CD44 regulates epigenetic plasticity by mediating iron endocytosis. Nat. Chem. 2020, 12, 929-938. [CrossRef] [PubMed]

11. Al-Hajj, M.; Wicha, M.S.; Benito-Hernandez, A.; Morrison, S.J.; Clarke, M.F. Prospective identification of tumorigenic breast cancer cells. Proc. Natl. Acad. Sci. USA 2003, 100, 3983-3988. [CrossRef] [PubMed]

12. Tomita, H.; Tanaka, K.; Tanaka, T.; Hara, A. Aldehyde dehydrogenase 1A1 in stem cells and cancer. Oncotarget 2016, 7, 11018-11032. [CrossRef]

13. Smith, C.; Gasparetto, M.; Humphries, K.; Pollyea, D.A.; Vasiliou, V.; Jordan, C.T. Aldehyde dehydrogenases in acute myeloid leukemia: AML and ALDHs. Ann. N. Y. Acad. Sci. 2014, 1310, 58-68. [CrossRef] [PubMed]

14. Blume, R.; Rempel, E.; Manta, L.; Saeed, B.R.; Wang, W.; Raffel, S.; Ermakova, O.; Eckstein, V.; Benes, V.; Trumpp, A.; et al. The molecular signature of AML with increased ALDH activity suggests a stem cell origin. Leuk. Lymphoma. 2018, 59, 2201-2210. [CrossRef]

15. Rasper, M.; Schafer, A.; Piontek, G.; Teufel, J.; Brockhoff, G.; Ringel, F.; Heindl, S.; Zimmer, C.; Schlegel, J. Aldehyde dehydrogenase 1 positive glioblastoma cells show brain tumor stem cell capacity. Neuro-Oncology 2010, 12, 1024-1033. [CrossRef] [PubMed]

16. Luo, Y.; Dallaglio, K.; Chen, Y.; Robinson, W.A.; Robinson, S.E.; McCarter, M.D.; Wang, J.; Gonzalez, R.; Thompson, D.C.; Norris, D.A.; et al. ALDH1A Isozymes are Markers of Human Melanoma Stem Cells and Potential Therapeutic Targets: ALDH ${ }^{+}$ Cancer Stem Cells in Human Melanoma. Stem Cells 2012, 30, 2100-2113. [CrossRef]

17. Ginestier, C.; Hur, M.H.; Charafe-Jauffret, E.; Monville, F.; Dutcher, J.; Brown, M.; Jacquemier, J.; Viens, P.; Kleer, C.G.; Liu, S.; et al. ALDH1 Is a Marker of Normal and Malignant Human Mammary Stem Cells and a Predictor of Poor Clinical Outcome. Cell Stem Cell 2007, 1, 555-567. [CrossRef]

18. Bourseau-Guilmain, E.; Griveau, A.; Benoit, J.-P.; Garcion, E. The importance of the stem cell marker prominin-1/CD133 in the uptake of transferrin and in iron metabolism in human colon cancer Caco-2 cells. PLoS ONE 2011, 6, e25515. [CrossRef]

19. Glumac, P.M.; LeBeau, A.M. The role of CD133 in cancer: A concise review. Clin. Transl. Med. 2018, 7, e18. [CrossRef]

20. Wang, Y.-C.; Yo, Y.-T.; Lee, H.-Y.; Liao, Y.-P.; Chao, T.-K.; Su, P.-H.; Lai, H.-C. ALDH1-bright epithelial ovarian cancer cells are associated with CD44 expression, drug resistance, and poor clinical outcome. Am. J. Pathol. 2012, 180, 1159-1169. [CrossRef]

21. Collins, A.T.; Berry, P.A.; Hyde, C.; Stower, M.J.; Maitland, N.J. Prospective Identification of Tumorigenic Prostate Cancer Stem Cells. Cancer Res. 2005, 65, 10946-10951. [CrossRef] [PubMed]

22. Schatton, T.; Murphy, G.F.; Frank, N.Y.; Yamaura, K.; Waaga-Gasser, A.M.; Gasser, M.; Zhan, Q.; Jordan, S.; Duncan, L.M.; Weishaupt, C.; et al. Identification of cells initiating human melanomas. Nature 2008, 451, 345-349. [CrossRef]

23. Dalerba, P.; Dylla, S.J.; Park, I.-K.; Liu, R.; Wang, X.; Cho, R.W.; Hoey, T.; Gurney, A.; Huang, E.H.; Simeone, D.M.; et al. Phenotypic characterization of human colorectal cancer stem cells. Proc. Natl. Acad. Sci. USA 2007, 104, 10158-10163. [CrossRef] [PubMed]

24. Prince, M.E.; Sivanandan, R.; Kaczorowski, A.; Wolf, G.T.; Kaplan, M.J.; Dalerba, P.; Weissman, I.L.; Clarke, M.F.; Ailles, L.E. Identification of a subpopulation of cells with cancer stem cell properties in head and neck squamous cell carcinoma. Proc. Natl. Acad. Sci. USA 2007, 104, 973-978. [CrossRef]

25. Okano, M.; Konno, M.; Kano, Y.; Kim, H.; Kawamoto, K.; Ohkuma, M.; Haraguchi, N.; Yokobori, T.; Mimori, K.; Yamamoto, H.; et al. Human colorectal CD24 ${ }^{+}$cancer stem cells are susceptible to epithelial-mesenchymal transition. Int. J. Oncol. 2014, 45, 575-580. [CrossRef]

26. Kemper, K.; Grandela, C.; Medema, J.P. Molecular identification and targeting of colorectal cancer stem cells. Oncotarget 2010, 1, 387-395. [CrossRef]

27. Dana, H. CD166 as a Stem Cell Marker? A Potential Target for Therapy Colorectal Cancer? JSRT 2016, 1, 226-229. [CrossRef]

28. Zakaria, N.; Yusoff, N.M.; Zakaria, Z.; Lim, M.N.; Baharuddin, P.J.N.; Fakiruddin, K.S.; Yahaya, B. Human non-small cell lung cancer expresses putative cancer stem cell markers and exhibits the transcriptomic profile of multipotent cells. BMC Cancer 2015, 15, 84. [CrossRef] 
29. Chen, Y.; Yu, D.; Zhang, H.; He, H.; Zhang, C.; Zhao, W.; Shao, R. CD133 ${ }^{+}$EpCAM ${ }^{+}$Phenotype Possesses More Characteristics of Tumor Initiating Cells in Hepatocellular Carcinoma Huh7 Cells. Int. J. Biol. Sci. 2012, 8, 992-1004. [CrossRef]

30. Li, C.; Heidt, D.G.; Dalerba, P.; Burant, C.F.; Zhang, L.; Adsay, V.; Wicha, M.; Clarke, M.F.; Simeone, D.M. Identification of Pancreatic Cancer Stem Cells. Cancer Res. 2007, 67, 1030-1037. [CrossRef]

31. Saini, V.; Hose, C.D.; Monks, A.; Nagashima, K.; Han, B.; Newton, D.L.; Millione, A.; Shah, J.; Hollingshead, M.G.; Hite, K.M.; et al. Identification of CBX3 and ABCA5 as Putative Biomarkers for Tumor Stem Cells in Osteosarcoma. PLoS ONE 2012, 7, e41401. [CrossRef]

32. Kemper, K.; Sprick, M.R.; de Bree, M.; Scopelliti, A.; Vermeulen, L.; Hoek, M.; Zeilstra, J.; Pals, S.T.; Mehmet, H.; Stassi, G.; et al. The AC133 Epitope, but not the CD133 Protein, Is Lost upon Cancer Stem Cell Differentiation. Cancer Res. 2010, 70, 719-729. [CrossRef] [PubMed]

33. Yang, Z.F.; Ho, D.W.; Ng, M.N.; Lau, C.K.; Yu, W.C.; Ngai, P.; Chu, P.W.K.; Lam, C.T.; Poon, R.T.P.; Fan, S.T. Significance of CD90+ cancer stem cells in human liver cancer. Cancer Cell 2008, 13, 153-166. [CrossRef]

34. Bonnet, D.; Dick, J.E. Human acute myeloid leukemia is organized as a hierarchy that originates from a primitive hematopoietic cell. Nat. Med. 1997, 3, 730-737. [CrossRef]

35. Kong, Y.; Yoshida, S.; Saito, Y.; Doi, T.; Nagatoshi, Y.; Fukata, M.; Saito, N.; Yang, S.M.; Iwamoto, C.; Okamura, J.; et al. $\mathrm{CD} 34^{+} \mathrm{CD} 38^{+} \mathrm{CD} 19^{+}$as well as $\mathrm{CD} 34^{+} \mathrm{CD} 38^{-} \mathrm{CD} 19^{+}$cells are leukemia-initiating cells with self-renewal capacity in human B-precursor ALL. Leukemia 2008, 22, 1207-1213. [CrossRef] [PubMed]

36. Drakesmith, H.; Nemeth, E.; Ganz, T. Ironing out Ferroportin. Cell Metab. 2015, 22, 777-787. [CrossRef] [PubMed]

37. Vela, D.; Vela-Gaxha, Z. Differential regulation of hepcidin in cancer and non-cancer tissues and its clinical implications. Exp. Mol. Med. 2018, 50, e436. [CrossRef] [PubMed]

38. Schonberg, D.L.; Miller, T.E.; Wu, Q.; Flavahan, W.A.; Das, N.K.; Hale, J.S.; Hubert, C.G.; Mack, S.C.; Jarrar, A.M.; Karl, R.T.; et al. Preferential Iron Trafficking Characterizes Glioblastoma Stem-like Cells. Cancer Cell 2015, 28, 441-455. [CrossRef]

39. Mai, T.T.; Hamaï, A.; Hienzsch, A.; Cañeque, T.; Müller, S.; Wicinski, J.; Cabaud, O.; Leroy, C.; David, A.; Acevedo, V.; et al. Salinomycin kills cancer stem cells by sequestering iron in lysosomes. Nat. Chem. 2017, 9, 1025-1033. [CrossRef] [PubMed]

40. Hamaï, A.; Cañeque, T.; Müller, S.; Mai, T.T.; Hienzsch, A.; Ginestier, C.; Charafe-Jauffret, E.; Codogno, P.; Mehrpour, M.; Rodriguez, R. An iron hand over cancer stem cells. Autophagy 2017, 13, 1465-1466. [CrossRef]

41. Chanvorachote, P.; Luanpitpong, S. Iron induces cancer stem cells and aggressive phenotypes in human lung cancer cells. Am. J. Physiol. Cell Physiol. 2016, 310, C728-C739. [CrossRef]

42. Rychtarcikova, Z.; Lettlova, S.; Tomkova, V.; Korenkova, V.; Langerova, L.; Simonova, E.; Zjablovskaja, P.; Alberich-Jorda, M.; Neuzil, J.; Truksa, J. Tumor-initiating cells of breast and prostate origin show alterations in the expression of genes related to iron metabolism. Oncotarget 2017, 8, 6376-6398. [CrossRef]

43. Raggi, C.; Gammella, E.; Correnti, M.; Buratti, P.; Forti, E.; Andersen, J.B.; Alpini, G.; Glaser, S.; Alvaro, D.; Invernizzi, P.; et al. Dysregulation of Iron Metabolism in Cholangiocarcinoma Stem-like Cells. Sci. Rep. 2017, 7, 17667. [CrossRef]

44. Blanchette-Farra, N.; Kita, D.; Konstorum, A.; Tesfay, L.; Lemler, D.; Hegde, P.; Claffey, K.P.; Torti, F.M.; Torti, S.V. Contribution of three-dimensional architecture and tumor-associated fibroblasts to hepcidin regulation in breast cancer. Oncogene 2018, 37, 4013-4032. [CrossRef] [PubMed]

45. Bootcov, M.R.; Bauskin, A.R.; Valenzuela, S.M.; Moore, A.G.; Bansal, M.; He, X.Y.; Zhang, H.P.; Donnellan, M.; Mahler, S.; Pryor, K.; et al. MIC-1, a novel macrophage inhibitory cytokine, is a divergent member of the TGF-beta superfamily. Proc. Natl. Acad. Sci. USA 1997, 94, 11514-11519. [CrossRef] [PubMed]

46. Park, Y.J.; Lee, H.; Lee, J.-H. Macrophage inhibitory cytokine-1 transactivates ErbB family receptors via the activation of Src in SK-BR-3 human breast cancer cells. BMB Rep. 2010, 43, 91-96. [CrossRef] [PubMed]

47. Sasahara, A.; Tominaga, K.; Nishimura, T.; Yano, M.; Kiyokawa, E.; Noguchi, M.; Noguchi, M.; Kanauchi, H.; Ogawa, T.; Minato, H.; et al. An autocrine/paracrine circuit of growth differentiation factor (GDF) 15 has a role for maintenance of breast cancer stem-like cells. Oncotarget 2017, 8, 24869-24881. [CrossRef]

48. Basuli, D.; Tesfay, L.; Deng, Z.; Paul, B.; Yamamoto, Y.; Ning, G.; Xian, W.; McKeon, F.; Lynch, M.; Crum, C.P.; et al. Iron addiction: A novel therapeutic target in ovarian cancer. Oncogene 2017, 36, 4089-4099. [CrossRef]

49. Song, S.; Christova, T.; Perusini, S.; Alizadeh, S.; Bao, R.-Y.; Miller, B.W.; Hurren, R.; Jitkova, Y.; Gronda, M.; Isaac, M.; et al. Wnt inhibitor screen reveals iron dependence of $\beta$-catenin signaling in cancers. Cancer Res. 2011, 71, 7628-7639. [CrossRef] [PubMed]

50. Doyard, M.; Fatih, N.; Monnier, A.; Island, M.L.; Aubry, M.; Leroyer, P.; Bouvet, R.; Chalès, G.; Mosser, J.; Loréal, O.; et al. Iron excess limits HHIPL-2 gene expression and decreases osteoblastic activity in human MG-63 cells. Osteoporos. Int. 2012, 23, 2435-2445. [CrossRef] [PubMed]

51. Yang, L.; Shi, P.; Zhao, G.; Xu, J.; Peng, W.; Zhang, J.; Zhang, G.; Wang, X.; Dong, Z.; Chen, F.; et al. Targeting cancer stem cell pathways for cancer therapy. Signal Transduct. Target. Ther. 2020, 5, 8. [CrossRef] [PubMed]

52. West, N.R.; Murray, J.I.; Watson, P.H. Oncostatin-M promotes phenotypic changes associated with mesenchymal and stem cell-like differentiation in breast cancer. Oncogene 2014, 33, 1485-1494. [CrossRef] [PubMed]

53. Xie, G.; Yao, Q.; Liu, Y.; Du, S.; Liu, A.; Guo, Z.; Sun, A.; Ruan, J.; Chen, L.; Ye, C.; et al. IL-6-induced epithelial-mesenchymal transition promotes the generation of breast cancer stem-like cells analogous to mammosphere cultures. Int. J. Oncol. 2012, 40, 1171-1179. [CrossRef] 
54. Marotta, L.L.C.; Almendro, V.; Marusyk, A.; Shipitsin, M.; Schemme, J.; Walker, S.R.; Bloushtain-Qimron, N.; Kim, J.J.; Choudhury, S.A.; Maruyama, R.; et al. The JAK2/STAT3 signaling pathway is required for growth of CD44 ${ }^{+}$CD24 $4^{-}$stem cell-like breast cancer cells in human tumors. J. Clin. Investig. 2011, 121, 2723-2735. [CrossRef]

55. Guo, L.; Chen, C.; Shi, M.; Wang, F.; Chen, X.; Diao, D.; Hu, M.; Yu, M.; Qian, L.; Guo, N. Stat3-coordinated Lin-28-let-7-HMGA2 and miR-200-ZEB1 circuits initiate and maintain oncostatin M-driven epithelial-mesenchymal transition. Oncogene 2013, 32, 5272-5282. [CrossRef]

56. Lobello, N.; Biamonte, F.; Pisanu, M.E.; Faniello, M.C.; Jakopin, Ž.; Chiarella, E.; Giovannone, E.D.; Mancini, R.; Ciliberto, G.; Cuda, G.; et al. Ferritin heavy chain is a negative regulator of ovarian cancer stem cell expansion and epithelial to mesenchymal transition. Oncotarget 2016, 7, 62019-62033. [CrossRef]

57. Samimi, A.; Khodayar, M.J.; Alidadi, H.; Khodadi, E. The Dual Role of ROS in Hematological Malignancies: Stem Cell Protection and Cancer Cell Metastasis. Stem. Cell Rev. Rep. 2020, 16, 262-275. [CrossRef] [PubMed]

58. Kobayashi, C.I.; Suda, T. Regulation of reactive oxygen species in stem cells and cancer stem cells. J. Cell Physiol. 2012, 227, 421-430. [CrossRef]

59. Diehn, M.; Cho, R.W.; Lobo, N.A.; Kalisky, T.; Dorie, M.J.; Kulp, A.N.; Qian, D.; Lam, J.S.; Ailles, L.E.; Wong, M.; et al. Association of reactive oxygen species levels and radioresistance in cancer stem cells. Nature 2009, 458, 780-783. [CrossRef] [PubMed]

60. Arnold, C.R.; Mangesius, J.; Skvortsova, I.-I.; Ganswindt, U. The Role of Cancer Stem Cells in Radiation Resistance. Front. Oncol. 2020, 10, 164. [CrossRef]

61. Kim, Y.S.; Kang, M.J.; Cho, Y.M. Low production of reactive oxygen species and high DNA repair: Mechanism of radioresistance of prostate cancer stem cells. Anticancer Res. 2013, 33, 4469-4474.

62. Scaramuzzino, L.; Lucchino, V.; Scalise, S.; Lo Conte, M.; Zannino, C.; Sacco, A.; Biamonte, F.; Parrotta, E.I.; Costanzo, F.S.; Cuda, G. Uncovering the Metabolic and Stress Responses of Human Embryonic Stem Cells to FTH1 Gene Silencing. Cells 2021, 10, 2431. [CrossRef]

63. Zolea, F.; Battaglia, A.M.; Chiarella, E.; Malanga, D.; Marco, C.D.; Bond, H.M.; Morrone, G.; Costanzo, F.; Biamonte, F. Ferritin Heavy Subunit Silencing Blocks the Erythroid Commitment of K562 Cells via miR-150 up-Regulation and GATA-1 Repression. Int. J. Mol. Sci. 2017, 18, 2167. [CrossRef]

64. Salatino, A.; Aversa, I.; Battaglia, A.M.; Sacco, A.; Di Vito, A.; Santamaria, G.; Chirillo, R.; Veltri, P.; Tradigo, G.; Di Cello, A.; et al. H-Ferritin Affects Cisplatin-Induced Cytotoxicity in Ovarian Cancer Cells through the Modulation of ROS. Oxidative Med. Cell. Longev. 2019, 2019, 1-13. [CrossRef] [PubMed]

65. Mani, S.A.; Guo, W.; Liao, M.-J.; Eaton, E.Ng.; Ayyanan, A.; Zhou, A.Y.; Brooks, M.; Reinhard, F.; Zhang, C.C.; Shipitsin, M.; et al. The Epithelial-Mesenchymal Transition Generates Cells with Properties of Stem Cells. Cell 2008, 133, 704-715. [CrossRef] [PubMed]

66. Aversa, I.; Zolea, F.; Ieranò, C.; Bulotta, S.; Trotta, A.M.; Faniello, M.C.; De Marco, C.; Malanga, D.; Biamonte, F.; Viglietto, G.; et al. Epithelial-to-mesenchymal transition in FHC-silenced cells: The role of CXCR4/CXCL12 axis. J. Exp. Clin. Cancer Res. 2017, 36, 104. [CrossRef] [PubMed]

67. Li, R.; Luo, C.; Mines, M.; Zhang, J.; Fan, G.-H. Chemokine CXCL12 Induces Binding of Ferritin Heavy Chain to the Chemokine Receptor CXCR4, Alters CXCR4 Signaling, and Induces Phosphorylation and Nuclear Translocation of Ferritin Heavy Chain. J. Biol. Chem. 2006, 281, 37616-37627. [CrossRef]

68. Zhang, K.-H.; Tian, H.-Y.; Gao, X.; Lei, W.-W.; Hu, Y.; Wang, D.-M.; Pan, X.-C.; Yu, M.-L.; Xu, G.-J.; Zhao, F.-K.; et al. Ferritin Heavy Chain-Mediated Iron Homeostasis and Subsequent Increased Reactive Oxygen Species Production Are Essential for Epithelial-Mesenchymal Transition. Cancer Res. 2009, 69, 5340-5348. [CrossRef]

69. Chirillo, R.; Aversa, I.; Di Vito, A.; Salatino, A.; Battaglia, A.M.; Sacco, A.; Di Sanzo, M.A.; Faniello, M.C.; Quaresima, B.; Palmieri, C.; et al. FtH-Mediated ROS Dysregulation Promotes CXCL12/CXCR4 Axis Activation and EMT-Like TransDifferentiation in Erythroleukemia K562 Cells. Front. Oncol. 2020, 10, 698. [CrossRef]

70. Gong, A.-H.; Wei, P.; Zhang, S.; Yao, J.; Yuan, Y.; Zhou, A.-D.; Lang, F.F.; Heimberger, A.B.; Rao, G.; Huang, S. FoxM1 Drives a Feed-Forward STAT3-Activation Signaling Loop That Promotes the Self-Renewal and Tumorigenicity of Glioblastoma Stem-like Cells. Cancer Res. 2015, 75, 2337-2348. [CrossRef]

71. Zhang, S.; Zhao, B.S.; Zhou, A.; Lin, K.; Zheng, S.; Lu, Z.; Chen, Y.; Sulman, E.P.; Xie, K.; Bögler, O.; et al. m6A Demethylase ALKBH5 Maintains Tumorigenicity of Glioblastoma Stem-like Cells by Sustaining FOXM1 Expression and Cell Proliferation Program. Cancer Cell 2017, 31, 591-606.E6. [CrossRef]

72. Liu, Y.; Yuan, Q.; Xie, L. The AlkB Family of Fe (II)/Alpha-Ketoglutarate-Dependent Dioxygenases Modulates Embryogenesis through Epigenetic Regulation. Curr. Stem Cell Res. Ther. 2018, 13, 136-143. [CrossRef]

73. Zhang, C.; Zhi, W.I.; Lu, H.; Samanta, D.; Chen, I.; Gabrielson, E.; Semenza, G.L. Hypoxia-inducible factors regulate pluripotency factor expression by ZNF217- and ALKBH5-mediated modulation of RNA methylation in breast cancer cells. Oncotarget 2016, 7, 64527-64542. [CrossRef] [PubMed]

74. Jiang, X.; Zhang, C.; Qi, S.; Guo, S.; Chen, Y.; Du, E.; Zhang, H.; Wang, X.; Liu, R.; Qiao, B.; et al. Elevated expression of ZNF217 promotes prostate cancer growth by restraining ferroportin-conducted iron egress. Oncotarget 2016, 7, 84893-84906. [CrossRef]

75. Giovannetti, E.; Zucali, P.A.; Assaraf, Y.G.; Funel, N.; Gemelli, M.; Stark, M.; Thunnissen, E.; Hou, Z.; Muller, I.B.; Struys, E.A.; et al Role of proton-coupled folate transporter in pemetrexed resistance of mesothelioma: Clinical evidence and new pharmacological tools. Ann. Oncol. 2017, 28, 2725-2732. [CrossRef] [PubMed] 
76. Wang, R.-H.; Li, C.; Xu, X.; Zheng, Y.; Xiao, C.; Zerfas, P.; Cooperman, S.; Eckhaus, M.; Rouault, T.; Mishra, L.; et al. A role of SMAD4 in iron metabolism through the positive regulation of hepcidin expression. Cell Metab. 2005, 2, 399-409. [CrossRef] [PubMed]

77. Wang, W.; Di, X.; Torti, S.V.; Torti, F.M. Ferritin H induction by histone deacetylase inhibitors. Biochem. Pharmacol. 2010, 80, 316-324. [CrossRef]

78. Wang, Y.-F.; Zhang, J.; Su, Y.; Shen, Y.-Y.; Jiang, D.-X.; Hou, Y.-Y.; Geng, M.-Y.; Ding, J.; Chen, Y. G9a regulates breast cancer growth by modulating iron homeostasis through the repression of ferroxidase hephaestin. Nat. Commun. 2017, 8, 274. [CrossRef] [PubMed]

79. Roatsch, M.; Hoffmann, I.; Abboud, M.I.; Hancock, R.L.; Tarhonskaya, H.; Hsu, K.-F.; Wilkins, S.E.; Yeh, T.-L.; Lippl, K.; Serrer, K.; et al. The Clinically Used Iron Chelator Deferasirox Is an Inhibitor of Epigenetic JumonjiC Domain-Containing Histone Demethylases. ACS Chem. Biol. 2019, 14, 1737-1750. [CrossRef]

80. Sarno, F.; Papulino, C.; Franci, G.; Andersen, J.H.; Cautain, B.; Melardo, C.; Altucci, L.; Nebbioso, A. 3-Chloro-N'-(2hydroxybenzylidene) benzohydrazide: An LSD1-Selective Inhibitor and Iron-Chelating Agent for Anticancer Therapy. Front. Pharmacol. 2018, 9, 1006. [CrossRef]

81. Cao, L.-L.; Liu, H.; Yue, Z.; Liu, L.; Pei, L.; Gu, J.; Wang, H.; Jia, M. Iron chelation inhibits cancer cell growth and modulates global histone methylation status in colorectal cancer. Biometals 2018, 31, 797-805. [CrossRef]

82. Feinberg, A.P.; Ohlsson, R.; Henikoff, S. The epigenetic progenitor origin of human cancer. Nat. Rev. Genet. 2006, 7, 21-33. [CrossRef]

83. Sharma, S.V.; Lee, D.Y.; Li, B.; Quinlan, M.P.; Takahashi, F.; Maheswaran, S.; McDermott, U.; Azizian, N.; Zou, L.; Fischbach, M.A.; et al. A chromatin-mediated reversible drug-tolerant state in cancer cell subpopulations. Cell 2010, 141, 69-80. [CrossRef]

84. Roesch, A.; Fukunaga-Kalabis, M.; Schmidt, E.C.; Zabierowski, S.E.; Brafford, P.A.; Vultur, A.; Basu, D.; Gimotty, P.; Vogt, T.; Herlyn, M. A temporarily distinct subpopulation of slow-cycling melanoma cells is required for continuous tumor growth. Cell 2010, 141, 583-594. [CrossRef] [PubMed]

85. Dixon, S.J.; Lemberg, K.M.; Lamprecht, M.R.; Skouta, R.; Zaaitsev, E.M.; Gleason, C.E.; Patel, D.N.; Bauer, A.J.; Cantley, A.M.; Yang, W.S.; et al. Ferroptosis: An iron-dependent form of nonapoptotic cell death. Cell 2012, 149, 1060-1072. [CrossRef] [PubMed]

86. Xie, Y.; Hou, W.; Song, X.; Yu, Y.; Huang, J.; Sun, X.; Kang, R.; Tang, D. Ferroptosis: Process and function. Cell Death Differ. 2016, 23, 369-379. [CrossRef] [PubMed]

87. Stockwell, B.R.; Friedmann Angeli, J.P.; Bayir, H.; Bush, A.I.; Conrad, M.; Dixon, S.J.; Fulda, S.; Gascón, S.; Hatzios, S.K.; Kagan, V.E.; et al. Ferroptosis: A Regulated Cell Death Nexus Linking Metabolism, Redox Biology, and Disease. Cell 2017, 171, 273-285. [CrossRef] [PubMed]

88. Galluzzi, L.; Vitale, I.; Aaronson, S.A.; Abrams, J.M.; Adam, D.; Agostinis, P.; Alnemri, E.S.; Altucci, L.; Amelio, I.; Andrews, D.W.; et al. Molecular mechanisms of cell death: Recommendations of the Nomenclature Committee on Cell Death 2018. Cell Death Differ. 2018, 25, 486-541. [CrossRef] [PubMed]

89. Yagoda, N.; von Rechenberg, M.; Zaganjor, E.; Bauer, A.J.; Yang, W.S.; Fridman, D.J.; Wolpaw, A.J.; Smukste, I.; Peltier, J.M.; Boniface, J.J.; et al. RAS-RAF-MEK-dependent oxidative cell death involving voltage-dependent anion channels. Nature 2007, 447, 864-868. [CrossRef]

90. Friedmann Angeli, J.P.; Schneider, M.; Proneth, B.; Tyurina, Y.Y.; Tyurin, V.A.; Hammond, V.J.; Herbach, N.; Aichler, M.; Walch, A.; Eggenhofer, E.; et al. Inactivation of the ferroptosis regulator Gpx4 triggers acute renal failure in mice. Nat. Cell Biol. 2014, 16, 1180-1191. [CrossRef]

91. Ray, P.D.; Huang, B.-W.; Tsuji, Y. Reactive oxygen species (ROS) homeostasis and redox regulation in cellular signaling. Cell. Signal. 2012, 24, 981-990. [CrossRef]

92. Kagan, V.E.; Mao, G.; Qu, F.; Angeli, J.P.F.; Doll, S.; Croix, C.S.; Dar, H.H.; Liu, B.; Tyurin, V.A.; Ritov, V.B.; et al. Oxidized arachidonic and adrenic PEs navigate cells to ferroptosis. Nat. Chem. Biol. 2017, 13, 81-90. [CrossRef] [PubMed]

93. Cao, J.Y.; Dixon, S.J. Mechanisms of ferroptosis. Cell. Mol. Life Sci. 2016, 73, 2195-2209. [CrossRef] [PubMed]

94. D'Herde, K.; Krysko, D.V. Ferroptosis: Oxidized PEs trigger death. Nat. Chem. Biol. 2017, 13, 4-5. [CrossRef] [PubMed]

95. Louandre, C.; Ezzoukhry, Z.; Godin, C.; Barbare, J.-C.; Mazière, J.-C.; Chauffert, B.; Galmiche, A. Iron-dependent cell death of hepatocellular carcinoma cells exposed to sorafenib. Int. J. Cancer 2013, 133, 1732-1742. [CrossRef]

96. Gao, M.; Monian, P.; Quadri, N.; Ramasamy, R.; Jiang, X. Glutaminolysis and Transferrin Regulate Ferroptosis. Mol. Cell. 2015, 59, 298-308. [CrossRef]

97. Yang, W.S.; Stockwell, B.R. Synthetic lethal screening identifies compounds activating iron-dependent, nonapoptotic cell death in oncogenic-RAS-harboring cancer cells. Chem. Biol. 2008, 15, 234-245. [CrossRef]

98. Angeli, J.P.F.; Shah, R.; Pratt, D.A.; Conrad, M. Ferroptosis Inhibition: Mechanisms and Opportunities. Trends Pharmacol. Sci. 2017, 38, 489-498. [CrossRef] [PubMed]

99. Yant, L.J.; Ran, Q.; Rao, L.; Van Remmen, H.; Shibatani, T.; Belter, J.G.; Motta, L.; Richardson, A.; Prolla, T.A. The selenoprotein GPX4 is essential for mouse development and protects from radiation and oxidative damage insults. Free Radic. Biol. Med. 2003, 34, 496-502. [CrossRef] 
100. Linkermann, A.; Skouta, R.; Himmerkus, N.; Mulay, S.R.; Dewitz, C.; De Zen, F.; Prokai, A.; Zuchtriegel, G.; Krombach, F.; Welz, P.-S.; et al. Synchronized renal tubular cell death involves ferroptosis. Proc. Natl. Acad. Sci. USA 2014, 111, 16836-16841. [CrossRef]

101. Skouta, R.; Dixon, S.J.; Wang, J.; Dunn, D.E.; Orman, M.; Shimada, K.; Rosenberg, P.A.; Lo, D.C.; Weinberg, J.M.; Linkermann, A.; et al. Ferrostatins inhibit oxidative lipid damage and cell death in diverse disease models. J. Am. Chem. Soc. 2014, 136, 4551-4556. [CrossRef] [PubMed]

102. Hao, S.; Liang, B.; Huang, Q.; Dong, S.; Wu, Z.; He, W.; Shi, M. Metabolic networks in ferroptosis. Oncol. Lett. 2018, $15,5405-5411$. [CrossRef] [PubMed]

103. Lewerenz, J.; Hewett, S.J.; Huang, Y.; Lambros, M.; Gout, P.W.; Kalivas, P.W.; Massie, A.; Smolders, I.; Methner, A.; Pergande, M.; et al. The cystine/glutamate antiporter system $\mathrm{x}_{\mathrm{c}}{ }^{-}$in health and disease: From molecular mechanisms to novel therapeutic opportunities. Antioxid. Redox Signal. 2013, 18, 522-555. [CrossRef] [PubMed]

104. Latunde-Dada, G.O. Ferroptosis: Role of lipid peroxidation, iron and ferritinophagy. Biochim. Biophys. Acta Gen. Subj. 2017, 1861, 1893-1900. [CrossRef]

105. Hayano, M.; Yang, W.S.; Corn, C.K.; Pagano, N.C.; Stockwell, B.R. Loss of cysteinyl-tRNA synthetase (CARS) induces the transsulfuration pathway and inhibits ferroptosis induced by cystine deprivation. Cell Death Differ. 2016, 23, 270-278. [CrossRef]

106. Shimada, K.; Skouta, R.; Kaplan, A.; Yang, W.S.; Hayano, M.; Dixon, S.J.; Brown, L.M.; Valenzuela, C.A.; Wolpaw, A.J.; Stockwell, B.R. Global survey of cell death mechanisms reveals metabolic regulation of ferroptosis. Nat. Chem. Biol. 2016, 12, 497-503. [CrossRef]

107. Doll, S.; Freitas, F.P.; Shah, R.; Aldrovandi, M.; da Silva, M.C.; Ingold, I.; Goya Grocin, A.; Xavier da Silva, T.N.; Panzilius, E.; Scheel, C.H.; et al. FSP1 is a glutathione-independent ferroptosis suppressor. Nature 2019, 575, 693-698. [CrossRef]

108. Krishan, S.; Jansson, P.J.; Gutierrez, E.; Lane, D.J.R.; Richardson, D.E.S.; Sahni, S. Iron metabolism and autophagy: A poorly explored relationship that has important consequences for health and disease. Nagoya J. Med. Sci. 2015, 77, 1-6.

109. Mancias, J.D.; Pontano Vaites, L.; Nissim, S.; Biancur, D.E.; Kim, A.J.; Wang, X.; Liu, Y.; Goessling, W.; Kimmelman, A.C.; Harper, J.W. Ferritinophagy via NCOA4 is required for erythropoiesis and is regulated by iron dependent HERC2-mediated proteolysis. eLife 2015, 4, e10308. [CrossRef] [PubMed]

110. Gao, M.; Monian, P.; Pan, Q.; Zhang, W.; Xiang, J.; Jiang, X. Ferroptosis is an autophagic cell death process. Cell. Res. 2016, 26, 1021-1032. [CrossRef]

111. Hou, W.; Xie, Y.; Song, X.; Sun, X.; Lotze, M.T.; Zeh, H.J.; Kang, R.; Tang, D. Autophagy promotes ferroptosis by degradation of ferritin. Autophagy 2016, 12, 1425-1428. [CrossRef]

112. Du, J.; Wang, T.; Li, Y.; Zhou, Y.; Wang, X.; Yu, X.; Ren, X.; An, Y.; Wu, Y.; Sun, W.; et al. DHA inhibits proliferation and induces ferroptosis of leukemia cells through autophagy dependent degradation of ferritin. Free Radic. Biol. Med. 2019, 131, 356-369. [CrossRef] [PubMed]

113. Lin, R.; Zhang, Z.; Chen, L.; Zhou, Y.; Zou, P.; Feng, C.; Wang, L.; Liang, G. Dihydroartemisinin (DHA) induces ferroptosis and causes cell cycle arrest in head and neck carcinoma cells. Cancer Lett. 2016, 381, 165-175. [CrossRef] [PubMed]

114. Zhu, S.; Zhang, Q.; Sun, X.; Zeh, H.J.; Lotze, M.T.; Kang, R.; Tang, D. HSPA5 Regulates Ferroptotic Cell Death in Cancer Cells. Cancer Res. 2017, 77, 2064-2077. [CrossRef]

115. Wu, Z.; Geng, Y.; Lu, X.; Shi, Y.; Wu, G.; Zhang, M.; Shan, B.; Pan, H.; Yuan, J. Chaperone-mediated autophagy is involved in the execution of ferroptosis. Proc. Natl. Acad. Sci. USA 2019, 116, 2996-3005. [CrossRef]

116. Liu, K.; Czaja, M.J. Regulation of lipid stores and metabolism by lipophagy. Cell Death Differ. 2013, 20, 3-11. [CrossRef]

117. Li, Z.; Yuan, Y.; Meng, Y.; Rong, Y.; Bai, H.; Chen, L. Autophagy upregulation ameliorates cell injury in Sequestosome 1 knockout podocytes in vitro. Biochem. Biophys. Res. Commun. 2017, 490, 98-103. [CrossRef]

118. Schroeder, B.; Schulze, R.J.; Weller, S.G.; Sletten, A.C.; Casey, C.A.; McNiven, M.A. The small GTPase Rab7 as a central regulator of hepatocellular lipophagy. Hepatology 2015, 61, 1896-1907. [CrossRef]

119. Yang, M.; Chen, P.; Liu, J.; Zhu, S.; Kroemer, G.; Klionsky, D.J.; Lotze, M.T.; Zeh, H.J.; Kang, R.; Tang, D. Clockophagy is a novel selective autophagy process favoring ferroptosis. Sci Adv. 2019, 5, eaaw2238. [CrossRef] [PubMed]

120. Song, X.; Zhu, S.; Chen, P.; Hou, W.; Wen, Q.; Liu, J.; Xie, Y.; Liu, J.; Klionsky, D.J.; Kroemer, G.; et al. AMPK-Mediated BECN1 Phosphorylation Promotes Ferroptosis by Directly Blocking System Xc ${ }^{-}$Activity. Curr. Biol. 2018, 28, 2388-2399.e5. [CrossRef]

121. Zhang, Z.; Yao, Z.; Wang, L.; Ding, H.; Shao, J.; Chen, A.; Zhang, F.; Zheng, S. Activation of ferritinophagy is required for the RNA-binding protein ELAVL1/HuR to regulate ferroptosis in hepatic stellate cells. Autophagy 2018, 14, 2083-2103. [CrossRef]

122. Ye, F.; Chai, W.; Xie, M.; Yang, M.; Yu, Y.; Cao, L.; Yang, L. HMGB1 regulates erastin-induced ferroptosis via RAS-JNK/p38 signaling in HL-60/NRASQ61L cells. Am. J. Cancer Res. 2019, 9, 730-739. [PubMed]

123. Tang, D.; Kang, R.; Livesey, K.M.; Cheh, C.-W.; Farkas, A.; Loughran, P.; Hoppe, G.; Bianchi, M.E.; Tracey, K.J.; Zeh, H.J.; et al. Endogenous HMGB1 regulates autophagy. J. Cell. Biol. 2010, 190, 881-892. [CrossRef] [PubMed]

124. Tang, D.; Kang, R.; Cheh, C.-W.; Livesey, K.M.; Liang, X.; Schapiro, N.E.; Benschop, R.; Sparvero, L.J.; Amoscato, A.A.; Tracey, K.J.; et al. HMGB1 release and redox regulates autophagy and apoptosis in cancer cells. Oncogene 2010, 29, 5299-5310. [CrossRef] [PubMed]

125. Li, J.; Liu, J.; Xu, Y.; Wu, R.; Chen, X.; Song, X.; Zeh, H.; Kang, R.; Klionsky, D.J.; Wang, X.; et al. Tumor heterogeneity in autophagy-dependent ferroptosis. Autophagy 2021, 17, 1-14. [CrossRef] 
126. Zhang, J.-F.; Yan, X.-M.; Lan, B.; Lei, Y.-R.; Li, X.-H.; Gao, S.; Guo, Y.-F.; Guo, F. Molecular mechanisms of synergistic induction of apoptosis by the combination therapy with hyperthermia and cisplatin in prostate cancer cells. Biochem. Biophys. Res. Commun. 2016, 479, 159-165. [CrossRef]

127. Wang, Y.-Q.; Chang, S.-Y.; Wu, Q.; Gou, Y.-J.; Jia, L.; Cui, Y.-M.; Yu, P.; Shi, Z.-H.; Wu, W.-S.; Gao, G.; et al. The Protective Role of Mitochondrial Ferritin on Erastin-Induced Ferroptosis. Front. Aging Neurosci. 2016, 8, 308. [CrossRef]

128. Sun, X.; Ou, Z.; Chen, R.; Niu, X.; Chen, D.; Kang, R.; Tang, D. Activation of the p62-Keap1-NRF2 pathway protects against ferroptosis in hepatocellular carcinoma cells. Hepatology 2016, 63, 173-184. [CrossRef]

129. Wu, K.C.; Cui, J.Y.; Klaassen, C.D. Beneficial role of Nrf2 in regulating NADPH generation and consumption. Toxicol. Sci. 2011, 123, 590-600. [CrossRef]

130. Adedoyin, O.; Boddu, R.; Traylor, A.; Lever, J.M.; Bolisetty, S.; George, J.F.; Agarwal, A. Heme oxygenase-1 mitigates ferroptosis in renal proximal tubule cells. Am. J. Physiol. Renal. Physiol. 2018, 314, F702-F714. [CrossRef]

131. Shin, D.; Kim, E.H.; Lee, J.; Roh, J.-L. Nrf2 inhibition reverses resistance to GPX4 inhibitor-induced ferroptosis in head and neck cancer. Free Radic. Biol. Med. 2018, 129, 454-462. [CrossRef]

132. Chen, D.; Tavana, O.; Chu, B.; Erber, L.; Chen, Y.; Baer, R.; Gu, W. NRF2 Is a Major Target of ARF in p53-Independent Tumor Suppression. Mol. Cell 2017, 68, 224-232.e4. [CrossRef]

133. Garg, A.D.; Dudek, A.M.; Ferreira, G.B.; Verfaillie, T.; Vandenabeele, P.; Krysko, D.V.; Mathieu, C.; Agostinis, P. ROS-induced autophagy in cancer cells assists in evasion from determinants of immunogenic cell death. Autophagy 2013, 9, $1292-1307$. [CrossRef] [PubMed]

134. Liu, Y.; Wang, Y.; Liu, J.; Kang, R.; Tang, D. Interplay between MTOR and GPX4 signaling modulates autophagy-dependent ferroptotic cancer cell death. Cancer Gene Ther. 2021, 28, 55-63. [CrossRef]

135. Zhang, Y.; Swanda, R.V.; Nie, L.; Liu, X.; Wang, C.; Lee, H.; Lei, G.; Mao, C.; Koppula, P.; Cheng, W.; et al. mTORC1 couples cyst(e)ine availability with GPX4 protein synthesis and ferroptosis regulation. Nat. Commun. 2021, 12, 1589. [CrossRef]

136. Lu, B.; Chen, X.B.; Ying, M.D.; He, Q.J.; Cao, J.; Yang, B. The Role of Ferroptosis in Cancer Development and Treatment Response. Front. Pharmacol. 2017, 8, 992. [CrossRef] [PubMed]

137. Kang, R.; Kroemer, G.; Tang, D. The tumor suppressor protein p53 and the ferroptosis network. Free Radic. Biol. Med. 2019, 133, 162-168. [CrossRef] [PubMed]

138. Liu, J.; Zhang, C.; Wang, J.; Hu, W.; Feng, Z. The Regulation of Ferroptosis by Tumor Suppressor p53 and its Pathway. Int. J. Mol. Sci. 2020, 21, 8387. [CrossRef]

139. Jiang, L.; Kon, N.; Li, T.; Wang, S.-J.; Su, T.; Hibshoosh, H.; Baer, R.; Gu, W. Ferroptosis as a p53-mediated activity during tumour suppression. Nature 2015, 520,57-62. [CrossRef]

140. Ou, Y.; Wang, S.-J.; Li, D.; Chu, B.; Gu, W. Activation of SAT1 engages polyamine metabolism with p53-mediated ferroptotic responses. Proc. Natl. Acad. Sci. USA 2016, 113, E6806-E6812. [CrossRef] [PubMed]

141. Hu, W.; Zhang, C.; Wu, R.; Sun, Y.; Levine, A.; Feng, Z. Glutaminase 2, a novel p53 target gene regulating energy metabolism and antioxidant function. Proc. Natl. Acad. Sci. USA 2010, 107, 7455-7460. [CrossRef] [PubMed]

142. Xie, Y.; Zhu, S.; Song, X.; Sun, X.; Fan, Y.; Liu, J.; Zhong, M.; Yuan, H.; Zhang, L.; Billiar, T.R.; et al. The Tumor Suppressor p53 Limits Ferroptosis by Blocking DPP4 Activity. Cell. Rep. 2017, 20, 1692-1704. [CrossRef]

143. Lam, C.S.-C.; Cheung, A.H.-K.; Wong, S.K.-M.; Wan, T.M.-H.; Ng, L.; Chow, A.K.-M.; Cheng, N.S.-M.; Pak, R.C.-H.; Li, H.-S.; Man, J.H.-W.; et al. Prognostic significance of CD26 in patients with colorectal cancer. PLoS ONE 2014, 9, e98582. [CrossRef]

144. Pang, R.; Law, W.L.; Chu, A.C.Y.; Poon, J.T.; Lam, C.S.C.; Chow, A.K.M.; Ng, L.; Cheung, L.W.H.; Lan, X.R.; Lan, H.Y.; et al. A subpopulation of $\mathrm{CD}^{2} 6^{+}$cancer stem cells with metastatic capacity in human colorectal cancer. Cell Stem Cell 2010, 6, 603-615. [CrossRef]

145. Chen, D.; Chu, B.; Yang, X.; Liu, Z.; Jin, Y.; Kon, N.; Rabadan, R.; Jiang, X.; Stockwell, B.R.; Gu, W. iPLA2 $\beta$-mediated lipid detoxification controls p53-driven ferroptosis independent of GPX4. Nat. Commun. 2021, 12, 3644. [CrossRef]

146. Yi, M.; Li, J.; Chen, S.; Cai, J.; Ban, Y.; Peng, Q.; Zhou, Y.; Zeng, Z.; Peng, S.; Li, X.; et al. Emerging role of lipid metabolism alterations in Cancer stem cells. J. Exp. Clin. Cancer Res. 2018, 37, 118. [CrossRef]

147. Fujihara, K.M.; Zhang, B.Z.; Clemons, N.J. Opportunities for Ferroptosis in Cancer Therapy. Antioxidants 2021, 10, 986. [CrossRef] [PubMed]

148. Birsen, R.; Larrue, C.; Decroocq, J.; Johnson, N.; Guiraud, N.; Gotanegre, M.; Cantero-Aguilar, L.; Grignano, E.; Huynh, T.; Fontenay, M.; et al. APR-246 induces early cell death by ferroptosis in acute myeloid leukemia. Haematologica 2021. [CrossRef]

149. Liu, D.S.; Duong, C.P.; Haupt, S.; Montgomery, K.G.; House, C.M.; Azar, W.J.; Pearson, H.B.; Fisher, O.M.; Read, M.; Guerra, G.R.; et al. Inhibiting the system xC-/glutathione axis selectively targets cancers with mutant-p53 accumulation. Nat. Commun. 2017, 8, 14844. [CrossRef] [PubMed]

150. Jones, C.L.; Stevens, B.M.; D’Alessandro, A.; Culp-Hill, R.; Reisz, J.A.; Pei, S.; Gustafson, A.; Khan, N.; DeGregori, J.; Pollyea, D.A.; et al. Cysteine depletion targets leukemia stem cells through inhibition of electron transport complex II. Blood 2019, 134, 389-394. [CrossRef]

151. Ishimoto, T.; Nagano, O.; Yae, T.; Tamada, M.; Motohara, T.; Oshima, H.; Oshima, M.; Ikeda, T.; Asaba, R.; Yagi, H.; et al. CD44 variant regulates redox status in cancer cells by stabilizing the $\mathrm{xCT}$ subunit of system $\mathrm{xc}^{-}$and thereby promotes tumor growth. Cancer Cell 2011, 19, 387-400. [CrossRef] [PubMed]

152. Nagano, O. Cancer therapy targeted to CD44v-xCT-mediated antioxidant system. Ann. Oncol. 2016, 27, vii40. [CrossRef] 
153. Yoshikawa, M.; Tsuchihashi, K.; Ishimoto, T.; Yae, T.; Motohara, T.; Sugihara, E.; Onishi, N.; Masuko, T.; Yoshizawa, K.; Kawashiri, S.; et al. xCT inhibition depletes CD44v-expressing tumor cells that are resistant to EGFR-targeted therapy in head and neck squamous cell carcinoma. Cancer Res. 2013, 73, 1855-1866. [CrossRef]

154. Sun, X.; Ou, Z.; Xie, M.; Kang, R.; Fan, Y.; Niu, X.; Wang, H.; Cao, L.; Tang, D. HSPB1 as a novel regulator of ferroptotic cancer cell death. Oncogene 2015, 34, 5617-5625. [CrossRef]

155. Tang, D.; Kang, R.; Livesey, K.M.; Kroemer, G.; Billiar, T.R.; Van Houten, B.; Zeh, H.J.; Lotze, M.T. High-mobility group box 1 is essential for mitochondrial quality control. Cell Metab. 2011, 13, 701-711. [CrossRef] [PubMed]

156. Shen, L.; Qi, Z.; Zhu, Y.; Song, X.; Xuan, C.; Ben, P.; Lan, L.; Luo, L.; Yin, Z. Phosphorylated heat shock protein 27 promotes lipid clearance in hepatic cells through interacting with STAT3 and activating autophagy. Cell. Signal. 2016, 28, 1086-1098. [CrossRef] [PubMed]

157. Chen, C.-L.; Uthaya Kumar, D.B.; Punj, V.; Xu, J.; Sher, L.; Tahara, S.M.; Hess, S.; Machida, K. NANOG Metabolically Reprograms Tumor-Initiating Stem-like Cells through Tumorigenic Changes in Oxidative Phosphorylation and Fatty Acid Metabolism. Cell Metab. 2016, 23, 206-219. [CrossRef] [PubMed]

158. Marzenell, P.; Hagen, H.; Sellner, L.; Zenz, T.; Grinyte, R.; Pavlov, V.; Daum, S.; Mokhir, A. Aminoferrocene-based prodrugs and their effects on human normal and cancer cells as well as bacterial cells. J. Med. Chem. 2013, 56, 6935-6944. [CrossRef]

159. Hagen, H.; Marzenell, P.; Jentzsch, E.; Wenz, F.; Veldwijk, M.R.; Mokhir, A. Aminoferrocene-based prodrugs activated by reactive oxygen species. J. Med. Chem. 2012, 55, 924-934. [CrossRef]

160. Trujillo-Alonso, V.; Pratt, E.C.; Zong, H.; Lara-Martinez, A.; Kaittanis, C.; Rabie, M.O.; Longo, V.; Becker, M.W.; Roboz, G.J.; Grimm, J.; et al. FDA-approved ferumoxytol displays anti-leukaemia efficacy against cells with low ferroportin levels. Nat. Nanotechnol. 2019, 14, 616-622. [CrossRef]

161. Sagasser, J.; Ma, B.N.; Baecker, D.; Salcher, S.; Hermann, M.; Lamprecht, J.; Angerer, S.; Obexer, P.; Kircher, B.; Gust, R. A New Approach in Cancer Treatment: Discovery of Chlorido[N, $\mathrm{N}^{\prime}$-disalicylidene-1,2-phenylenediamine]iron(III) Complexes as Ferroptosis Inducers. J. Med. Chem. 2019, 62, 8053-8061. [CrossRef]

162. Gao, J.; Luo, T.; Wang, J. Gene interfered-ferroptosis therapy for cancers. Nat. Commun. 2021, 12, 5311. [CrossRef]

163. Yu, H.; Yang, C.; Jian, L.; Guo, S.; Chen, R.; Li, K.; Qu, F.; Tao, K.; Fu, Y.; Luo, F.; et al. Sulfasalazine-induced ferroptosis in breast cancer cells is reduced by the inhibitory effect of estrogen receptor on the transferrin receptor. Oncol. Rep. 2019, 42, 826-838. [CrossRef]

164. Okazaki, S.; Shintani, S.; Hirata, Y.; Suina, K.; Semba, T.; Yamasaki, J.; Umene, K.; Ishikawa, M.; Saya, H.; Nagano, O. Synthetic lethality of the ALDH3A1 inhibitor dyclonine and xCT inhibitors in glutathione deficiency-resistant cancer cells. Oncotarget 2018, 9, 33832-33843. [CrossRef]

165. Gout, P.W.; Buckley, A.R.; Simms, C.R.; Bruchovsky, N. Sulfasalazine, a potent suppressor of lymphoma growth by inhibition of the $\mathrm{x}_{\mathrm{c}}{ }^{-}$cystine transporter: A new action for an old drug. Leukemia 2001, 15, 1633-1640. [CrossRef]

166. Yamaguchi, Y.; Kasukabe, T.; Kumakura, S. Piperlongumine rapidly induces the death of human pancreatic cancer cells mainly through the induction of ferroptosis. Int. J. Oncol. 2018, 52, 1011-1022. [CrossRef] [PubMed]

167. Robert, S.M.; Buckingham, S.C.; Campbell, S.L.; Robel, S.; Holt, K.T.; Ogunrinu-Babarinde, T.; Warren, P.P.; White, D.M.; Reid, M.A.; Eschbacher, J.M.; et al. SLC7A11 expression is associated with seizures and predicts poor survival in patients with malignant glioma. Sci. Transl. Med. 2015, 7, 289ra86. [CrossRef] [PubMed]

168. Robe, P.A.; Martin, D.H.; Nguyen-Khac, M.T.; Artesi, M.; Deprez, M.; Albert, A.; Vanbelle, S.; Califice, S.; Bredel, M.; Bours, V. Early termination of ISRCTN45828668, a phase $1 / 2$ prospective, randomized study of sulfasalazine for the treatment of progressing malignant gliomas in adults. BMC Cancer 2009, 9, 372. [CrossRef] [PubMed]

169. Lachaier, E.; Louandre, C.; Godin, C.; Saidak, Z.; Baert, M.; Diouf, M.; Chauffert, B.; Galmiche, A. Sorafenib induces ferroptosis in human cancer cell lines originating from different solid tumors. Anticancer Res. 2014, 34, 6417-6422.

170. Shaw, A.T.; Winslow, M.M.; Magendantz, M.; Ouyang, C.; Dowdle, J.; Subramanian, A.; Lewis, T.A.; Maglathin, R.L.; Tolliday, N.; Jacks, T. Selective killing of K-ras mutant cancer cells by small molecule inducers of oxidative stress. Proc. Natl. Acad. Sci. USA 2011, 108, 8773-8778. [CrossRef]

171. Yu, Y.; Xie, Y.; Cao, L.; Yang, L.; Yang, M.; Lotze, M.T.; Zeh, H.J.; Kang, R.; Tang, D. The ferroptosis inducer erastin enhances sensitivity of acute myeloid leukemia cells to chemotherapeutic agents. Mol. Cell. Oncol. 2015, 2, e1054549. [CrossRef] [PubMed]

172. Yang, W.S.; SriRamaratnam, R.; Welsch, M.E.; Shimada, K.; Skouta, R.; Viswanathan, V.S.; Cheah, J.H.; Clemons, P.A.; Shamji, A.F.; Clish, C.B.; et al. Regulation of ferroptotic cancer cell death by GPX4. Cell 2014, 156, 317-331. [CrossRef]

173. Malfa, G.A.; Tomasello, B.; Acquaviva, R.; Genovese, C.; La Mantia, A.; Cammarata, F.P.; Ragusa, M.; Renis, M.; Di Giacomo, C. Betula etnensis Raf. (Betulaceae) Extract Induced HO-1 Expression and Ferroptosis Cell Death in Human Colon Cancer Cells. Int. J. Mol. Sci. 2019, 20, 2723. [CrossRef] [PubMed]

174. Gaschler, M.M.; Andia, A.A.; Liu, H.; Csuka, J.M.; Hurlocker, B.; Vaiana, C.A.; Heindel, D.W.; Zuckerman, D.S.; Bos, P.H.; Reznik, E.; et al. FINO2 initiates ferroptosis through GPX4 inactivation and iron oxidation. Nat. Chem. Biol. 2018, 14, 507-515. [CrossRef] [PubMed]

175. Abrams, R.P.; Carroll, W.L.; Woerpel, K.A. Five-Membered Ring Peroxide Selectively Initiates Ferroptosis in Cancer Cells. ACS Chem. Biol. 2016, 11, 1305-1312. [CrossRef] [PubMed]

176. Eling, N.; Reuter, L.; Hazin, J.; Hamacher-Brady, A.; Brady, N.R. Identification of artesunate as a specific activator of ferroptosis in pancreatic cancer cells. Oncoscience 2015, 2, 517-532. [CrossRef] 
177. Yang, N.-D.; Tan, S.-H.; Ng, S.; Shi, Y.; Zhou, J.; Tan, K.S.W.; Wong, W.-S.F.; Shen, H.-M. Artesunate induces cell death in human cancer cells via enhancing lysosomal function and lysosomal degradation of ferritin. J. Biol. Chem. 2014, 289, 33425-33441. [CrossRef]

178. Ooko, E.; Saeed, M.E.M.; Kadioglu, O.; Sarvi, S.; Colak, M.; Elmasaoudi, K.; Janah, R.; Greten, H.J.; Efferth, T. Artemisinin derivatives induce iron-dependent cell death (ferroptosis) in tumor cells. Phytomedicine 2015, 22, 1045-1054. [CrossRef]

179. Wang, N.; Zeng, G.-Z.; Yin, J.-L.; Bian, Z.-X. Artesunate activates the ATF4-CHOP-CHAC1 pathway and affects ferroptosis in Burkitt's Lymphoma. Biochem. Biophys. Res. Commun. 2019, 519, 533-539. [CrossRef]

180. Chen, Y.; Mi, Y.; Zhang, X.; Ma, Q.; Song, Y.; Zhang, L.; Wang, D.; Xing, J.; Hou, B.; Li, H.; et al. Dihydroartemisinin-induced unfolded protein response feedback attenuates ferroptosis via PERK/ATF4/HSPA5 pathway in glioma cells. J. Exp. Clin. Cancer Res. 2019, 38, 402. [CrossRef]

181. Bebber, C.M.; Thomas, E.S.; Stroh, J.; Chen, Z.; Androulidaki, A.; Schmitt, A.; Höhne, M.N.; Stüker, L.; de Pádua Alves, C.; Khonsari, A.; et al. Ferroptosis response segregates small cell lung cancer (SCLC) neuroendocrine subtypes. Nat. Commun. 2021, 12, 2048. [CrossRef]

182. Ma, S.; Henson, E.S.; Chen, Y.; Gibson, S.B. Ferroptosis is induced following siramesine and lapatinib treatment of breast cancer cells. Cell Death Dis. 2016, 7, e2307. [CrossRef] [PubMed]

183. Ma, S.; Dielschneider, R.F.; Henson, E.S.; Xiao, W.; Choquette, T.R.; Blankstein, A.R.; Chen, Y.; Gibson, S.B. Ferroptosis and autophagy induced cell death occur independently after siramesine and lapatinib treatment in breast cancer cells. PLoS ONE 2017, 12, e0182921. [CrossRef] [PubMed]

184. Gentric, G.; Kieffer, Y.; Mieulet, V.; Goundiam, O.; Bonneau, C.; Nemati, F.; Hurbain, I.; Raposo, G.; Popova, T.; Stern, M.-H.; et al. PML-Regulated Mitochondrial Metabolism Enhances Chemosensitivity in Human Ovarian Cancers. Cell Metab. 2019, 29, 156-173.e10. [CrossRef]

185. Badgley, M.A.; Kremer, D.M.; Maurer, H.C.; DelGiorno, K.E.; Lee, H.-J.; Purohit, V.; Sagalovskiy, I.R.; Ma, A.; Kapilian, J.; Firl, C.E.M.; et al. Cysteine depletion induces pancreatic tumor ferroptosis in mice. Science 2020, 368, 85-89. [CrossRef]

186. Cramer, S.L.; Saha, A.; Liu, J.; Tadi, S.; Tiziani, S.; Yan, W.; Triplett, K.; Lamb, C.; Alters, S.E.; Rowlinson, S.; et al. Systemic depletion of L-cyst(e)ine with cyst(e)inase increases reactive oxygen species and suppresses tumor growth. Nat. Med. 2017, 23, 120-127. [CrossRef] [PubMed]

187. Wang, W.; Green, M.; Choi, J.E.; Gijón, M.; Kennedy, P.D.; Johnson, J.K.; Liao, P.; Lang, X.; Kryczek, I.; Sell, A.; et al. CD8 ${ }^{+}$T cells regulate tumour ferroptosis during cancer immunotherapy. Nature 2019, 569, 270-274. [CrossRef]

188. Bjarnadottir, O.; Romero, Q.; Bendahl, P.-O.; Jirström, K.; Rydén, L.; Loman, N.; Uhlén, M.; Johannesson, H.; Rose, C.; Grabau, D.; et al. Targeting HMG-CoA reductase with statins in a window-of-opportunity breast cancer trial. Breast Cancer Res. Treat. 2013, 138, 499-508. [CrossRef]

189. Graf, H.; Jüngst, C.; Straub, G.; Dogan, S.; Hoffmann, R.-T.; Jakobs, T.; Reiser, M.; Waggershauser, T.; Helmberger, T.; Walter, A.; et al. Chemoembolization combined with pravastatin improves survival in patients with hepatocellular carcinoma. Digestion 2008, 78, 34-38. [CrossRef]

190. Kornblau, S.M.; Banker, D.E.; Stirewalt, D.; Shen, D.; Lemker, E.; Verstovsek, S.; Estrov, Z.; Faderl, S.; Cortes, J.; Beran, M.; et al. Blockade of adaptive defensive changes in cholesterol uptake and synthesis in AML by the addition of pravastatin to idarubicin + high-dose Ara-C: A phase 1 study. Blood 2007, 109, 2999-3006. [CrossRef]

191. Sondergaard, T.E.; Pedersen, P.T.; Andersen, T.L.; Søe, K.; Lund, T.; Ostergaard, B.; Garnero, P.; Delaisse, J.-M.; Plesner, T. A phase II clinical trial does not show that high dose simvastatin has beneficial effect on markers of bone turnover in multiple myeloma. Hematol. Oncol. 2009, 27, 17-22. [CrossRef] [PubMed] 